\title{
Potret Harmoni Kehidupan Keagamaan di Kabupaten Bojonegoro
}

\author{
Ahmad Zainul Hamdi \\ UIN Sunan Ampel Surabaya \\ ahmadinung@gmail.com
}

\begin{abstract}
This study aims to investigate the reasons why violence and religious conflict occurred in Bojonegoro district do not lead to radical actions. Departing from the fundamental question, "why does violence and religious conflict not extend into radical actions even though the potential for religious radicalization exists and even explode into destructive social conflict?", this study found that there are two main factors that make religious life among believers in Bojonegoro keep running in balance and harmonious way, namely cultural and structural factors. The most important cultural factor is the existence of cross-cutting affiliation where there are neutral social spaces that make people from different backgrounds meet without being troubled by their primordial identity. Meanwhile, structural factors that prevent radical action and religious conflict are the presence of the State as a neutral and decisive party; institutionalization of assurance of freedom of faith; and the activeness of the State in early prevention and conflict mediation.

[Studi ini bertujuan untuk melihat mengapa di wilayah Bojonegoro kekerasan dan konflik keagamaan nyaris tidak pernah meledak secara berarti. Berangkat dari pertanyaan mendasar, faktor-faktor apakah yang menyebabkan tidak terjadi proses radikalisasi keagamaan, sekalipun terdapat beberapa potensi konflik yang sebetulnya bisa meledak menjadi kekerasan atau konflik sosial yang destruktif, penelitian ini menemukan bahwa ada dua faktor penting yang mampu menjaga kehidupan keagamaan masyarakat Bojonegoro tetap seimbang, yaitu kultural dan struktural. Faktor kultural terpenting adalah bekerjanya crosscutting affiliation. Terdapat ruang-ruang sosial netral yang mempertemukan orang-orang dari latar belakang berbeda, tanpa dibebani oleh identitas-identitas primordial. Sementara, faktor
\end{abstract}


struktural yang mencegah radikalisasi dan konflik keagamaan adalah hadirnya negara sebagai pihak yang netral dan tegas; institusionalisasi jaminan kebebasan berkeyakinan; dan keaktifan negara dalam melakukan pencegahan dini dan memediasi konflik.]

Keywords: cultural, structural, conflict, radicalization.

\section{Pendahuluan}

Berbagai studi tentang kehidupan keagamaan di wilayah Jawa Timur pasca-Reformasi '98 hampir tidak menjadikan Kabupaten Bojonegoro sebagai area studi yang menarik. Jika mempertimbangkan kecenderungan studi-studi sosial keagamaan di Indonesia pasca-Reformasi yang secara umum didominasi oleh tema-tema bangkitnya radikalisme dan kekerasan berbasis keyakinan, ${ }^{1}$ posisi Bojonegoro ini bisa dipahami. Jika dilihat dari sudut pandang eksotisme dalam isu-isu sosial-kebudayaan, Bojonegoro sering dipotret sebagai wilayah penting kehidupan komunitas Samin. ${ }^{2}$ Sementara, dalam isu-isu politik, keberhasilan Suyoto, yang berasal dari partai politik dengan kursi terkecil di DPRD, dalam pilkada Bojonegoro selama dua periode menjadi topik riset yang sangat menarik. ${ }^{3}$ Sejak dilakukannya eksplorasi minyak bumi oleh Exxon Mobil Cepu Limited, studi-studi di wilayah Bojonegoro lebih menekankan pada topik perubahan sosial dan potensi konflik sosial akibat proses industrialisasi.

\footnotetext{
${ }^{1}$ Beberapa studi dalam tema ini, misalnya, Robert W. Hefner, "Muslim Democrats and Islamist Violence in Post-Soeharto Indonesia," dalam Robert W. Hefner (ed.), Remaking Muslim Politics: Pluralism, Contestation, Democratization (Princeton, New Jersey: Princeton University Press, 2005); Anthony Bubalo \& Greg Fealy, Joining the Caravan? The Middle East, Islamism and Indonesia (Alexandria: Iowa Institute for International Policy, 2005); M. Imdadun Rahmat, Arus Baru Islam Radikal: Transmisi Revivalisme Islam Timur Tengab ke Indonesia (Jakarta: Erlangga, 2005); Jamhari \& Jajang Jahroni (ed.), Gerakan Salafi Radikal di Indonesia (Jakarta: PT Raja Grafindo Persada, 2004).

2 Siti Munawaroh, Chrisrtiyati Ariani, \& Suwarno, Etnografi Masyarakat Samin di Bojonegoro: Potret Masyarakat Samin dalam Memaknai Hidup, 2015.

3 Ali Sahab, Perilaku Memilih Masyarakat Bojonegoro dalam Pilkada, "Kenapa harus 'Toto'?", 2012.
} 
Bisa dikatakan, pada topik terakhir inilah studi-studi di wilayah Bojonegoro banyak dilakukan akhir-akhir ini. ${ }^{4}$

Dari sedikit riset yang mengangkat tema kehidupan sosial-keagamaan di Bojonegoro, studi Sunarti perlu dipertimbangkan. Studi ini memberi informasi tentang cara-cara masyarakat Desa Leran, Kecamatan Kalitidu, Bojonegoro, dalam membangun toleransi keagamaan antara pemeluk Islam dan Kristen, dalam konteks kehidupan desa yang dihuni oleh lebih dari satu pemeluk agama dengan jumlah yang relatif setara ${ }^{5}$

Sementara itu, studi ini sendiri bertujuan untuk melihat mengapa di wilayah Bojonegoro kekerasan dan konflik keagamaan nyaris tidak pernah meledak secara berarti. Faktor-faktor apakah yang menyebabkan tidak terjadi proses radikalisasi keagamaan, sekalipun terdapat beberapa potensi konflik yang sebetulnya bisa meledak menjadi kekerasan atau konflik sosial yang destruktif, sebagaimana di tempat lain.

Penelitian ini dilakukan selama dua bulan, Mei-Juni 2016. Data-data dikumpulkan dari dua sumber: literatur dan wawancara. Studi literatur dilakukan terhadap berbagai penelitian terdahulu dan informasi-informasi media. Sementara, wawancara mendalam dilakukan terhadap dua puluh tuju orang informan dengan latar belakang berbeda-beda (pemuka agama, pemimpin atau anggota organisasi kemasyarakatan, perwakilan pemerintah dan aparat keamanan, perwakilan media lokal, serta politisi dari beberapa partai politik).

Peneliti berangkat dari argumen bahwa proses radikalisasi/deradikalisasi keagamaan tidak semata-mata terkait dengan

\footnotetext{
${ }^{4}$ Yopindra Ego Prastawa, Implementasi Perda No. 23/2011 tentang Percepatan Pertumbuban Ekonomi Daerah dalam Pelaksanaan Eksplorasi dan Eksploitasi serta Pengolaban Minyak dan Gas Bumi di Kabupaten Bojonegoro, 2015; Udkhulu Fissilmi Kaafah, Industri dan Perubahan Sosial: Dampak Peralihan Fungsi Lahan Pertanian Menjadi Industri Migas di Desa Gayam Kecamatan Gayam Kabupaten Bojonegoro, Skripsi pada Universitas Islam Negeri Sunan Ampel Surabaya, 2016; Karnaji, dkk., Social Early Warning System untuk Mengantisipasi Konflik Sosial di Masyarakat, http://alhada-fisip11.web.unair.ic.id, diakses pada 14 Juni 2016.

${ }^{5}$ Sunarti, Kerukunan Antar Agama di Kampung Kristen: Studi Kasus di Dusun Kwangenrejo Desa Leran Kecamatan Kalitidu Kabupaten Bojonegoro, Skripsi pada Universitas Islam Negeri Sunan Ampel Surabaya, 2104.
} 
faktor ajaran/nilai/ideologi keagamaan tertentu. Seseorang menjadi radikal (intoleran) atau moderat (toleran) juga berkelindan dengan faktorfaktor lain, misalnya, kondisi psikologis, sosial, dan ekonomi yang dialaminya. ${ }^{6}$ Dengan kata lain, perasaan tersinggung oleh kelompok lain yang langsung maupun tidak langsung bersentuhan dengannya, lingkungan dan jaringan sosial di mana ia tumbuh dan bersosialisasi, termasuk di dalamnya adalah media, serta kondisi perekonomian yang dialami, turut menjadi faktor yang menyumbang "keputusan" seseorang untuk menjadi toleran atau intoleran. Yang tidak kalah pentingnya dalam proses ini adalah faktor-faktor struktural politik yang melibatkan regulasi dan tindakan aparatus negara. Faktor terakhir ini menyangkut kehadiran atau tidak hadiran negara dalam kasus-kasus konflik yang dialami warganya.

\section{Bojonegoro: Sebuah Wilayah yang Sedang Tumbuh}

Luas Kabupaten Bojonegoro adalah 230.706 Ha, di mana luas lahan sawah hanya 32,58\%, prosentase yang masih berada di bawah luas lahan hutan negara yang mencapai 40,15\%. Di sepanjang utara Bojonegoro merupakan Daerah Aliran Sungai (DAS) Bengawan Solo yang subur

\footnotetext{
${ }^{6}$ Istilah 'Islam radikal' yang dimaksudkan dalam tulisan ini adalah kelompok atau gerakan keagamaan Islam yang berjuang melakukan reformasi atau perubahan atas tata kehidupan sosial-budaya-politik secara mendasar dan menyeluruh (termasuk menuntut berdirinya negara Islam, berlakunya syariat Islam sebagai hukum negara, dipatuhinya ajaran Islam dalam kehidupan bermasyarakat), dan mereka menyetujui kekerasan sebagai sarana untuk mencapai tujuannya, baik mereka melakukan kekerasan atau tidak. Dalam kaitannya dengan penggunaan kekerasan, istilah 'radikal' bisa bersinonim dengan 'militan' yang secara harfiah bermakna “using force or strong pressure to achieve one's aims". Istilah 'militan' dalam pengertian ini juga digunakan Saeed ketika dia melabeli kelompok jihadis sebagai militant extremist. (Abdullah Saeed, "Trends in Contemporary Islam: A Preliminary Attempts at a Classification", The Muslim World, Vol. 97 [Juli 2007], 398). Sementara, Muslim moderat merujuk kepada kelompok Muslim yang tidak menyetujui kekerasan sebagai cara untuk mencapai tujuan, sebagaimana penjelasan Esposito, "Minimal, Muslim moderat adalah mereka yang hidup dan bekerja dalam masyarakat, mengusahakan perubahan dari bawah, menolak ekstremisme agama, dan menganggap kekerasan dan terorisme sebagai sesuatu yang haram. ...[Muslim] moderat merupakan kelompok masyarakat yang sangat beragam dan bermacam-macam yang...bisa menjangkau spektrum dari kelompok konservatif hingga reformis liberal". (John L. Esposito, "Muslim Moderat: Arus Utama Kelompok Modernis, Islamis, Konservatif, dan Tradisionalis", dalam Suaidi Asyari [ed.], Siapakah Muslim Moderat? Jjakarta: Kultura, 2008], 78-79).
} 
dengan pertanian yang ekstensif. Sementara di bagian selatan membentang pegunungan kapur yang merupakan bagian dari rangkaian Pegunungan Kendeng. ${ }^{7}$

Secara geografis, Kabupaten Bojonegoro terletak pada $111^{\circ} 25^{\prime}$ dan $112^{\circ} 09^{\prime}$ bujur timur, dan $6^{\circ} 59^{\prime}$ dan $7^{\circ} 37^{\prime}$ lintang selatan. Kabupaten Bojonegoro bisa dikatakan adalah sisi barat Provinsi Jawa Timur. Sebelah barat Kabupaten Bojonegoro berbatasan dengan Kabupaten Ngawi dan Blora (Jawa Tengah). Di sebelah utara, ia berbatasan dengan Kabupaten Tuban yang terletak di wilayah pesisir Laut Jawa. Melintas ke arah timur, Bojonegoro berbatasan dengan Kabupaten Lamongan, sedang di sebelah selatan, dia berbatasan dengan Kabupaten Madiun, Nganjuk, dan Jombang.

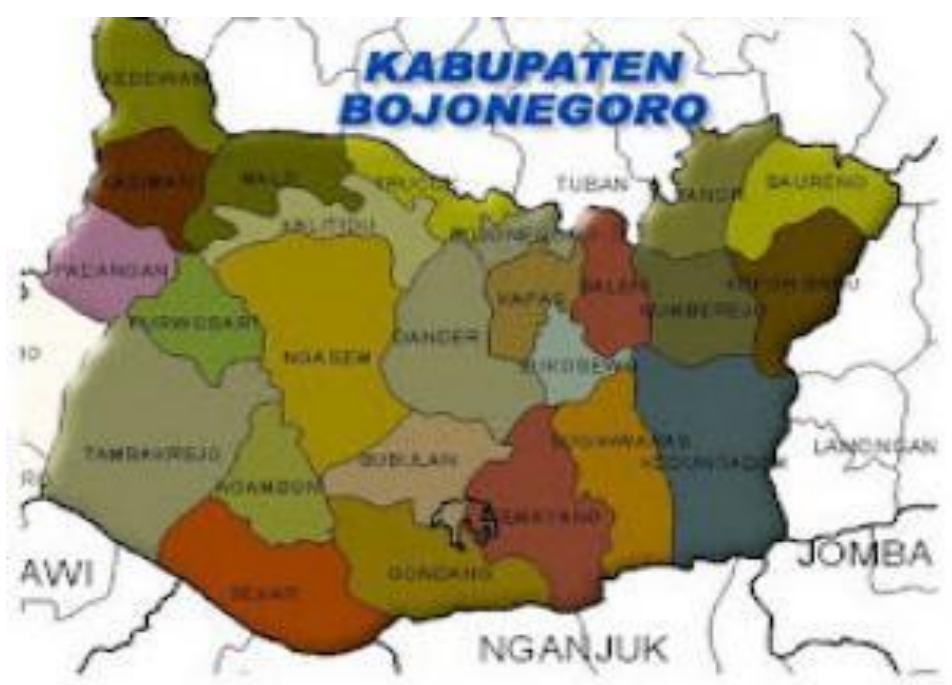

Peta Kabupaten Bojonegoro

Jika dilihat dari posisi geografisnya, Kabupaten Bojonegoro bisa dikatakan wilayah pedalaman yang secara budaya, lebih dekat dengan wilayah-wilayah kebudayaan Mataraman. Secara umum, masyarakat Bojonegoro termasuk masyarakat abangan. Sekalipun data statistik

\footnotetext{
7 "Buku Profil Kabupaten Bojonegoro Tahun 2012," (www.kanalbojonegoro.com), 2.
} 
menunjukkan bahwa umat Muslim Bojonegoro mencapai 1,423,022 dari total penduduknya 1,437,256, namun data ini sesungguhnya hanya mencerminkan angka berdasarkan catatan kolom agama pada KTP daripada menggambarkan nilai-nilai sosio-budaya yang dianut masyarakat Bojonegoro. Selama ini, Bojonegoro tidak masuk dalam kekuatan politik kaum santri. Bersama dengan wilayah-wilayah bekas Karesidenan Madiun (Madiun, Ngawi, Magetan, Ponorogo, Pacitan, dan Trenggalek) dan Kediri, Bojonegoro lebih dekat dengan partai berideologi nasionalissekuler, seperti PNI, PKI (Pemilu 1955).

Sekalipun komunitas Muslim tradisional terbilang sangat tinggi, sebagaimana wilayah-wilayah lain di Jawa Timur, namun tidak ada pesantren yang sangat berpengaruh di sini. Pesantren besar yang cukup berpengaruh di wilayah Bojonegoro adalah Pesantren Langitan yang berada di wilayah Kabupaten Tuban. Tidak mengherankan juga jika tidak ada tokoh agama Islam yang cukup berpengaruh dari Bojonegoro. Bahkan seorang penceramah yang sedang naik daun dari Bojonegoro, KH. Anwar Zahid, lebih dikenal di luar wilayahnya, dan bisa dikatakan "bukan siapasiapa" di wilayah Kabupaten Bojonegoro.

Penduduk Kabupaten Bojonegoro berjumlah 1.430.316 jiwa, terdiri atas 721.445 laki-laki dan 708.871 perempuan, yang sebagian besar didominasi usia produktif, yaitu mereka yang berusia antara 25-44 tahun. ${ }^{8}$ Tingginya usia angkatan kerja ini juga melahirkan problem sendiri terhadap ketersediaan lapangan kerja. Tahun 2009, Tingkat Partisipasi Angkatan Kerja (TPAK) di Kabupaten Bojonegoro tercatat sebesar $67,16 \%$, namun turun menjadi $66,62 \%$ di tahun 2010 , dan terus merosot hingga 50,36\% di tahun 2011. Jumlah lowongan kerja yang tersedia di tahun 2011, yaitu sebesar 1.750, jauh menurun dibandingkan tahun sebelumnya, yaitu sebanya 6.585 lowongan di tahun $2010{ }^{9}$

Sebagai daerah yang agraris, bayaknya kesempatan kerja secara kumulatif hingga tahun 2011 terbanyak pada sektor pertanian yaitu sebesar

\footnotetext{
8 "Buku Profil Kabupaten Bojonegoro Tahun 2012," 21.

${ }^{9}$ Ibid., 25.
} 
332.665 atau sekitar $44,72 \%$ dari kesempatan kerja yang ada. Disusul sektor perdagangan yaitu sebesar 16,96\%, sektor jasa dan lainnya sebesar $14,83 \% .^{10}$

Indeks sumber daya manusia Kabupaten Bojonegoro saat ini adalah 68, masih di bawah rata-rata Jawa Timur. Sekalipun pertumbuhan ekonomi mengalami perkembangan, namun jumlah penduduk miskin Kabupaten Bojonegoro masih di atas rata-rata Jawa Timur. ${ }^{11}$ Angka kemiskinan pada tahun 2011 tercatat $77.353 \mathrm{KK}$, menurun menjadi 77, $251 \mathrm{KK}$ pada tahun 2012. Nilai tukar petani (NTP) pada tahun 2010 mencapai 102,45\% meningkat menjadi $102,65 \%$ pada tahun 2011, namun mengalami penurunan lagi menjadi 102,50\% pada tahun 2012. Pertumbuhan ekonomi daerah (non migas) mengalami progres cukup baik, yaitu 5,82\% pada tahun 2008 menjadi $7,40 \%$ di tahun $2012 .{ }^{12}$

Sejak dulu, Kabupaten Bojonegoro dikenal sebagai wilayah miskin sekalipun sesungguhnya memiliki sumber daya alam yang cukup melimpah. Bahkan, kekayaan alam Bojonegoro yang melimpah itulah yang membuat Belanda tertarik untuk menguasainya. Dari Bojonegoro, Belanda berhasil mendapatkan minyak, kayu jati, tembakau dan berbagai tanaman produktif lain yang diminati pasar Eropa saat itu. Meski berlimpah sumber daya alam, masyarakat Bojonegoro dikenal sebagai masyarakat miskin. Hingga tahun 2007, Bojonegoro adalah Kabupaten termiskin ketiga di Jawa Timur. Penelitian Penders tentang Bojonegoro hingga tahun 1942 menyebutkan bahwa kemiskinan masyarakatnya sudah sangat mewabah. ${ }^{13}$

Akan tetapi, sejak di bawah kepemimpinan Bupati yang terpilih sejak 2008-2013 dan terpilih lagi untuk periode kedua, 2013-2018, Kabupaten Bojonegoro mengalami beberapa capaian yang sangat positif. Ditahun 2015, Pemkab Bojonegoro mendapatkan peringkat kedua di Jawa Timur untuk kategori laporan tahunan terbaik dan inovasi PPID terbaik, Urutan

\footnotetext{
${ }^{10}$ Ibid., 25.

11 "Mengelola Pembangunan Daerah Penghasil Migas," Imago, (2013), vii.

12 Ibid., ix.

${ }^{13}$ www.bojonegorokab.go.id, diakses pada 10 Mei 2016.
} 
kedua PPID terbaik 2015. Kabupaten Bojonegoro juga mendapatkan peringkat ketiga dalam peningkatan e-Government Indonesia (PeGi) tahap 3 tahun 2015. Juara pertama nasional dalam bidang Perpusdes juga digondolnya. Dalam bidang IT, Kabupaten Bojonegoro menjadi juara pertama "Kabupaten-Kota (Kabta) Web Awards 2015 yang diselenggarakan beritasatu.com.

Di tahun sebelumnya, 2014, Bupati Bojonegoro, Suyoto, ditetapkan sebagai pemimpin daerah inovatif 2014. Di tahun 2013, Bojonegoro juga menyabet penghargaan dari Gubernur Jawa Timur dalam bidang pelayanan publik percontohan Jawa Timur dengan predikat baik. Di antara berbagai penghargaan yang diraihnya, salah satu yang membanggakan adalah ditetapkannya Kabupaten Bojonegoro sebagai kabupaten/kota di Indonesia yang ramah HAM.

Jika dilihat pada data-data yang tersedia, berbagai penghargaan di atas bukanlah penilaian kosong. Setidaknya, terhitung sejak 2010, tidak pernah terjadi kekerasan akibat sikap intoleran. Berbagai keluhan masyarakat bisa langsung disuarakan melalui Media Center Bojonegoro (www.kanalbojonegoro.com). Melalui kanal yang sama, masyarakat Bojonegoro juga bisa mengakses APBD. Bahkan, Bupati Bojonegoro selalu mengadakan public hearing (diskusi publik) di pendopo kabupaten setiap Jumat sore, di mana semua elemen masyarakat yang berkepentingan bisa langsung menyuarakan permasalahan yang dihadapinya kepada Bupati. Berdasarkan penuturan Kepala Bakesbangpol Kabupaten Bojonegoro, setiap Jumat malam, Bupati menggelar rapat dengan SKPDSKPD yang bersangkutan untuk membicarakan laporan-laporan dari warga.

\section{Indonesia dan Jawa Timur Pasca-Reformasi: Sebuah Konteks}

Hingga saat ini, tidak sedikit orang yang masih gamang melihat masa depan Indonesia. Tidak jarang terdengar suara sumbang yang mempertanyakan apakah Indonesia sedang berjalan ke arah sebuah negara demokratis atau sebaliknya. Pesimisme ini tidak bisa diabaikan begitu saja jika kita melihat berbagai peristiwa yang mengikuti Reformasi politik '98. 
Kekerasan dengan motif agama dan etnis merupakan fenomena mencolok yang menandai kehidupan sosial-politik-keagamaan di Indonesia pascaSoeharto. ${ }^{14}$

Jika satu wajah Reformasi ditunjukkan melalui tuntutan yang sangat kuat terhadap keterbukaan dan demokrasi, maka proses demokratisasi ini sejak dini telah mendapati dirinya berhadapan dengan ancaman yang serius berupa konflik etnis dan agama. ${ }^{15}$ Bisa dikatakan, pada saat yang masih sangat dini pasca-Reformasi, kekuatan demokratik telah menemukan dirinya bukanlah kekuatan dominan dalam peta politik Indonesia baru. ${ }^{16}$

Situasi politik Indonesia pasca-Reformasi tidak hanya dipenuhi dengan persaingan antara kelompok prodemokrasi dengan sisa-sisa kekuatan politik rejim Orde Baru, tapi juga antara kelompok prodemokrasi dengan kekuatan-kekuatan keagamaan dan etnis yang ingin mengambil untung dari situasi yang ada. Tidak ada yang menduga bahwa chaos (kekacauan) politik yang diakibatkan Reformasi melahirkan banyak kekerasan dengan jargon agama. Jika kekerasan komunal yang dipantik oleh sentimen agama dan etnis ini tidak bisa dipecahkan, tidak menutup kemungkinan bahwa transisi demokrasi akan mengarah kepada otoritarianisme baru.

Tuntutan implementasi syariat Islam oleh kalangan islamis, misalnya, adalah suara lantang yang ingin menguasai ruang publik dengan memanfaatkan nalar dan instrumen demokrasi yang baru seumur jagung ini, yang potensial untuk membalik arah demokrasi yang sedang dibangun. Misalnya, pada Agustus 2000, ribuan umat Islam datang ke Yogyakarta menghadiri Kongres Mujahidin untuk membentuk MMI (Majelis

\footnotetext{
${ }^{14}$ Ahmad Suaedy, Agama dan Kekerasan Kolektif: Dilema Islam Indonesia Mengarungi Transisi Demokrasi," dalam Rumadi \& Ahmad Suaedy (ed.), Politisasi Agama dan Konflik Komunal: Beberapa Isu Penting di Indonesia (Jakarta: Wahid Institute, 2007), 343.

${ }^{15}$ Rizal Sukma, "Ethnic Conflict in Indonesia: Causes and the Quest for Solution," dalam Kusuma Snitwongse \& W. Scott Thompson ed.), Ethnic Conflict in South East Asia (Singapura: ISEAS, 2005), 1.

16 Robert W. Hefner, "Muslim Democrats and Islamist Violence in Post-Soeharto Indonesia," dalam Robert W. Hefner (ed.), Remaking Muslim Politics: Pluralism, Contestation, Democratization (Princeton and Oxford: Princeton University Press, 2005).
} 
Mujahidin Indonesia). Dalam pidato sambutannya, Abu Bakar Ba'asyir, tokoh sentral gerakan ini, mengatakan bahwa hanya ada dua pilihan bagi umat Islam dalam rangka menegakkan syariat Islam di Indonesia: terlaksananya syariat Islam atau "kami akan mati sebagai seorang mujahid." ${ }^{17}$ Demokrasi juga dianggap sebagai halangan bagi pelaksanaan syariat Islam. Sebagaimana tercatat dalam rekomendasi Kongres Mujahidin, "Menolak demokrasi, republik, sistem dan bentuk pemerintahan yang merupakan produk doktrin kaum kafir, dan menyerukan kaum Muslim untuk menghidupkan kembali sistem pemerintahan syura dan bentuk negara khilafah." ${ }^{18}$

Lebih dari itu, jika selama ini Indonesia bangga sebagai pemeluk Islam terbesar di dunia dan menjadi kiblat dari kehidupan keislaman yang moderat, maka pasca-reformasi, radikalisme menjadi salah satu wajah Islam Indonesia. Bahkan, Indonesia telah menjadi bagian dari jaringan terorisme internasional. Sejak tahun 2000, berbagai bom meledak di beberapa wilayah Indonesia. Bom Bali 2002 yang membunuh ratusan orang, dan bom Marriot Jakarta 2003 yang membunuh belasan orang, semakin meyakinkan kesan bahwa Indonesia telah masuk ke dalam front peperangan jaringan teroris internasional. Dari tahun 2008 sampai 2013, setidaknya ada lima kali kejadian bom bunuh diri yang dilakukan oleh orang-orang dari kelompok Muslim radikal. ${ }^{19}$ Ketika pada pertengahan tahun 2014 dunia dibuat shock (kaget) dengan berdirinya ISIS (Islamic State on Iraq and Syiria), Indonesia yang telah menjadi bagian dari jaringan terorisme global juga mau tidak mau mendapat imbas dari fenomena ini. Banyak Muslim Indonesia yang terang-terangan mendukung ISIS, bahkan terlibat dalam peperangan ISIS di Syiria.

Sebuah studi yang hendak mengukur efektivitas (dan kemungkinan kegagalan) gerakan demokrasi di Indonesia pasca-reformasi menyebutkan

\footnotetext{
${ }^{17}$ Abu bakar Ba'asyir, "Sambutan Ketua Abl al-Halli wa al-'Aqdi: Seruan ke Arah Tatbiq al-Shari'ab", dalam Irfan S. Awwa (ed.), Risalab Kongres Mujabidin dan Penegakan Syariah Islam (Yogyakarta: Wihdah Press, 2001), 139.

18 Awwas (ed.), Risalah Kongres Mujahidin, 158.

${ }^{19}$ Hefner, "Muslim Democrats and Islamist Violence," 274.
} 
bahwa di negara plural seperti Indonesia, di mana sebagian besar persaingan politik didasari oleh sentimen etnis dan agama, maka kuasa partisipasi yang dibangun oleh satu kekuatan politik sangat potensial mengarah pada penciptaan pemerintahan terdesentralisasi yang non demokratis. Ini bisa menjadi sisi gelap Reformasi politik Indonesia, di mana proses transisi tidak mengarah kepada terlembaganya demokrasi secara kokoh. Akan tetapi tetap harus dipertimbangkan keberadaan aktoraktor prodemokrasi yang memiliki komitmen untuk tetap mencari alternatif bahkan ketika jalan politik tampak buntu. Bahkan ketika consociationalism (pemerintahan dalam masyarakat majemuk) dipraktikkan, para aktor demokrasi tetap memiliki keinginan untuk melampaui golongan etnis dan agama dengan cara menahan gelombang dan mempromosikan bentuk-bentuk lain organisasi sosial politik. ${ }^{20}$

Dalam era transisi demokrasi, keberadaan aktor-aktor prodemokrasi memegang peranan penting dalam menjaga menguatnya religio/ethnionationalism. Setidaknya, inilah situasi yang bisa dilihat pada sosok Suyoto, Bupati Kabupaten Bojonegoro dalam menjaga wilayahnya dari kekerasan komunal yang melanda beberapa wilayah di Jawa Timur.

Jawa Timur sendiri bukanlah wilayah yang kedap dari kekerasan berbasis agama. Memang, selama ini Jawa Timur dianggap memiliki catatan rendah dalam hal kekerasan agama. Dari perspektif tertentu, penilaian ini bisa diterima. Dalam kasus Ahmadiyah, misalnya, Jawa Timur bisa dianggap sebagai wilayah surga jika dibandingkan dengan Jawa Barat. ${ }^{21}$ Akan tetapi, asumsi ini segera memudar jika kita melihat nilai indeks demokrasi Jawa Timur, di mana sebagian indikasinya adalah kebebasan

\footnotetext{
${ }^{20}$ Stanley Adi Prasetyo, A.E. Priyono, Olle Torrnquist, "Demokrat Mengambang," dalam Stanley Adi Prasetyo, A.E. Priyono, Olle Torrnquist (ed.), Gerakan Demokrasi di Indonesia Pasca-Soeharto (Jakarta: Demos, 2003), xii-xiii

${ }^{21}$ Pada 28 Februari 2011, Gubernur Jawa Timur mengeluarkan SK Larangan Aktivitas Jemaat Ahmadiyah Indonesia (JAI) di Jawa Timur. Banyak pihak yang kaget dengan keluarnya SK tersebut. Rata-rata, kekagetan itu justru dikarenakan selama ini komunitas Ahmadiyah di Jawa Timur dapat melakukan aktivitasnya dengan aman tanpa ada gangguan. Tidak ada catatan kekerasan yang dialami oleh komunitas Ahmadiyah di Jawa Timur.
} 
sipil dan politik serta pelembagaan demokrasi. Sampai tahun 2013, indeks demokrasi Jawa Timur tercatat buruk $(59,32)$, sedang di 2014, nilai ini meningkat hanya ke level sedang $(70,36){ }^{22}$

Penelitian CMARs selama tahun 2009 memperlihatkan bahwa di setiap saat dan waktu, Jawa Timur menyimpan potensi untuk meledak menjadi ketegangan dan konflik keagamaan yang terbuka. Laporan tersebut menyatakan kepada kita bahwa tuduhan sesat sangat mudah keluar untuk siapa saja yang dianggap berbeda. Sepanjang tahun 2010, ancaman terhadap kebebasan beragama (tuduhan sesat dan penodaan agama), kekerasan berbasis agama, perusakan tempat ibadah, fatwa-fatwa keagamaan bermasalah, dan regulasi diskriminatif secara mudah bisa ditemukan. ${ }^{23}$ Tahun 2011, Gubernur Jawa Timur mengeluarkan regulasi diskriminatif berupa Surat Keputusan (SK) No. 188/94/KPTS/013/2011 tentang Pelarangan Aktivitas Ahmadiyah Jawa Timur. Yang paling fenomenal tentu saja adalah ledakan kekerasan terhadap komunitas Syiah di Sampang pada tahun 2012. ${ }^{24}$ Kekerasan ini justru direspons oleh Gubernur Jawa timur dengan mengeluarkan satu lagi regulasi diskriminatif, yaitu Peraturan Gubernur (Pergub) No. 55 tahun 2012 tentang Pembinaan Kegiatan Keagamaan dan Pengawasan Aliran Sesat di Jawa Timur.

Dengan melihat situasi Jawa Timur tersebut, tidak berlebihan jika Kabupaten Bojonegoro tampak istimewa. Dari berbagai data kekerasan komunal di Jawa Timur pasca-reformasi, nyaris tidak ditemukan adanya

\footnotetext{
22 "Berita Resmi Statistik, BPS Jawa Timur, 2015.

${ }^{23}$ Tim CMARs, Ringkasan Eksekutif Berdamai dengan Kekerasan (Fakta Tindakan Intoleransi dan Pelanggaran Hak Kebebasan Beragama/Berkeyakinan di Jawa Timur 2010).

${ }^{24}$ Lihat Ahmad Zainul Hamdi, "Klaim Religious Authority dalam Konflik Sunni-Syiah Sampang Madura, Islamica, Vol. 6, No. 2 (Maret 2012), 215-231; Muhammad Afdillah, "Dari Masjid ke Panggung Politik: Studi Kasus Peran Pemuka Agama dan Politisi dalam Konflik Kekerasan Agama antara Komunitas Sunni dan Syiah di Sampang Jawa Timur", Tesis--UGM, Yogyakarta, 2013. Sementara publikasi untuk kepentingan kampanye advokasi, lihat newsletter yang diterbitkan oleh CMARs Surabaya: Syahadah, edisi 13 (Oktober 2011); Syahadah, edisi 16 (Januari 2012); Syahadah, edisi 17 (Februari 2012); Syahadah, edisi 18 (Maret 2012); Syahadah, edisi 19 (April 2012); Syahadah, edisi 20 (Mei 2012); Syahadah, edisi 21 (Juni 2012); dan Syahadah, edisi 22 (Juli 2012).
} 
konflik sosial dengan sentimen agama atau etnis di Bojonegoro. Bukan berarti di Bojonegoro tidak pernah ditemukan kasus-kasus keagamaan yang potensial meledak menjadi konflik komunal terbuka sebagaimana di wilayah lain. Namun, beberapa kasus tersebut berhasil diselesaikan dengan sangat proporsional.

\section{Tiga Kasus Keberhasilan Negara dalam Menyelesaikan Konflik:}

\section{Konflik Syiah Sukorejo: Ketegasan Polisi dan Kearifan Jamaah ${ }^{25}$}

Komunitas Syiah Bojonegoro bisa dikatakan baru berusia seumur jagung. Sekalipun embrionya bisa dilacak dari tahun 2001, namun komunitas Syiah sendiri baru secara resmi berdiri pada tahun 2003. Pada Juli 2001 sekelompok anak muda santri membuat pengajian akbar di pesantren kecil bernama Pon Pes “Al-Asy 'ari” pimpinan KH. Choirul Anam yang terletak di Dusun Ceweng, Desa Sendangrejo, Kecamatan Dander, Bojonegoro. Sejak awal kegiatan pengajian dirancang besarbesaran dengan tujuan untuk mengenalkan pesantren ke masyarakat luas.

Beberapa hari menjelang acara, digelar acara doa yang dihadiri dan dipimpin oleh Habib Ali Assegaf dari "Forum Habaib Seluruh Indonesia". Dari sinilah komunitas Syiah Bojonegoro bermula, yaitu ketika Habib Ali mengajak diskusi dua orang anak muda: Muhammad Hafi dan Ihsan Rifa'i (Ayik), salah satu anggota Jamiyah Hadrah al-Futuwwah, grup hadrah yang tampil di acara tersebut. Dalam diskusi yang berlangsung selama tiga hari itu, kedua anak muda ini sudah mulai menyadari bahwa Habib yang menjadi partner diskusinya adalah seorang Syiah. Sekalipun demikian, bukan rasa takut yang mereka rasakan, tapi justru ketertarikan yang mendalam. ${ }^{26}$

25 Data-data bagian ini bersumber pada catatan pribadi Muhammad Hafi, Pembina Yayasan Aba Zahra' dan Brains Community Bojonegoro (organisasi komunitas Syiah Bojonegoro), Asal-usul Komunitas Pencinta Ablil Bayt Bojonegoro, Surabaya, 15 Juni 2016, dan wawancara dengan yang bersangkutan pada 10 Mei 2016.

26 Kedua anak muda ini bisa dibilang santri Nahdlatul Ulama. Keduanya pernah mengenyam pendidikan pesantren di pondok NU. Wawancara dengan Irfan Rifa'i, Ketua Branis Community, organisasi sosial pengikut Syiah Bojonegoro, 19 Mei 2016. 
Tiga bulan setelah diskusi yang mengesankan tersebut, si Habib datang lagi ke Bojonegoro. Tampaknya kehadiran kedua ini secara khusus dirancang untuk menanamkan paham Syiah terutama kepada para komunitas pendukung acara pengajian di Pesantren Asy'ariyah tiga bulan sebelumnya. Semua rangkaian kegiatan yang dilakukan si Habib kali ini hanya memiliki satu tema: mengenalkan sejarah perjuangan Ahlul Bait dan menanamkan kecintaan kepada mereka. Salah satu tema penting yang dibahas adalah peristiwa terbunuhnya Sayyidina Husein bin Ali bin Abi Thalib di Padang Karbala atau yang dikenal dengan nama "Peristiwa Asyura" atau "Tragedi Karbala".

Anak-anak muda yang terpesona dengan ajaran sang Habib ini berniat melakukan peringatan Asyura dalam bentuk "Madrasah Karbala", suatu forum dialog ilmiah terbuka. Saudara Ihsan Rifa'i terpilih sebagai ketua panitia dan Muhammad Hafi sebagai sekretaris. Saat mengadakan acara Asyura ini, mereka sebetulnya sama sekali tidak merasa sebagai orang Syiah. Kesadaran mereka sepenuhnya masih sebagai anak-anak NU yang sedang melakukan haul terhadap cucu Nabi, salah seorang tokoh Islam, sebagaimana acara haul yang biasa dilakukan orang-orang NU terhadap tokoh ulama masa lalu.

Peringatan Asyura berupa dialog terbuka berlangsung selama sepuluh hari (15-24 Maret 2002) di serambi Masjid al-Mukhlisin Sukorejo, masjid tua di samping rumah Ihsan Rifai, di mana ketua takmir nya adalah ayahnya sendiri, H. Rohmat Munari. Acara puncaknya ditempatkan di lapangan desa Sukorejo, tepatnya di Dusun Kampung Baru. Hampir semua penceramah yang mengisi adalah para habib Syiah. Salah satu forum dialog yang panas adalah sesi yang dihadiri KH. Said Agil Siraj (saat itu menjabat sebagai salah satu Ketua Tanfidiyah PBNU), yang membawakan tema "Asyura dalam Tradisi Abl al-Sunnab wa al-Jamâ'ab".

Hingga saat itu, tidak ada satu pun masyarakat dan tokoh keagamaan di desa Sukorejo yang mempersoalkan secara ideologis perihal keberadaan kegiatan ini. Tentangan justru muncul dari pihak luar, yaitu sekelompok habib yang tergabung dalam "Yayasan Al-Bayyinat", organisasi Habaib 
yang misinya adalah memberantas paham Syiah di Indonesia”. Salah satu tokohnya adalah Habib Abdul Qodir bin Zen al-Jufri yang tinggal di Kecamatan Baureno Bojonegoro. Dari kelompok ini, isu Syiah di Bojonegoro mulai merembet ke dalam NU dan MUI Bojonegoro. Panitia diancam melalui telepon oleh kelompok al-Bayyinat untuk menggagalkan acara. Bahkan, Kepala Desa Sukorejo saat itu sempat mengeluarkan surat larangan terhadap kegiatan tersebut.

Bukannya mundur, panitia yang didominasi anak-anak muda ini justru semakin antusias. Mereka memasang spanduk peringatan Asyura dengan desain yang sangat mencolok, yang tersebar di 38 titik di seluruh wilayah Bojonegoro. Bahkan, untuk puncak acaranya, panitia mengirim undangan ke berbagai takmir masjid di seluruh kabupaten Bojonegoro. Panitia juga melakukan "woro-woro" keliling kampung/kota dengan menggunakan loud speaker (pengeras suara). Pasukan Banser dari GP Ansor Kabupaten Bojonegoro turut membantu mengamankan acara. Bupati Bojonegoro mengirimkan sambutan tertulisnya kepada panitia melalui Kepala Kesbangpol yang diutus menghadiri acara tersebut. Acaranya sendiri penuh dengan nuansa Syiah.

Sebegitu jauh reaksi negatif dari beberapa tokoh agama tidak membuat anak-anak muda pendukung acara Asyura ini merasa khawatir. Situasi "ayem" ini sesungguhnya lebih banyak disebabkan oleh tidakpahaman akan "bahaya" kegiatan ini terhadap kelompok Sunni yang merupakan kelompok mainstream di Indonesia. Mereka merasa bahwa acara haul merupakan acara yang biasa dilakukan di kalangan NU juga.

Masyarakat yang sejak awal mencium aroma keberadaan Syiah semakin mendapatkan justifikasi atas kecurigaannya. Reaksi terhadap Syiah mulai berlangsung di berbagai pengajian, bahkan di mimbar-mimbar khotbah Jumat. Reaksi semakin terbuka ketika ada acara peringatan Maulid Nabi di depan Masjid Jami' Kota Bojonegoro, di mana salah seorang penceramahnya, Habib Thohir Alkaf (Ketua Umum Al-Bayyinat Pusat), menghimbau secara terbuka agar masyarakat Bojonegoro tidak 
terpengaruh ajaran Syiah yang sedang dikembangkan oleh Remaja Masjid al-Mukhlisin Sukorejo.

Lambat namun pasti, anak-anak muda yang awalnya hanya menyelenggarakan haul Sayyidina Husein tersebut akhirnya sungguhsungguh menjadi pengikut Syiah. Kepastian ini terjadi di tahun 2003 ketika mereka dibimbing masalah Fiqh oleh Habib Ali Assegaf. Tentu saja mereka tidak memperlihatkan amaliah keagamaannya secara terbuka. Anak-anak muda yang memang sejak awal menjadi remaja masjid alMukhlisin tetap menjalankan tugas-tugas mereka, misalnya, menjadi petugas azan atau mengajar sekolah diniyah di masjid tersebut.

Dengan semakin eksis nya komunitas Syiah Bojonegoro, dibentuklah organisasi informal yang bernama "Komunitas Pencinta Ahlil Bayt Bojonegoro", yang diketuai oleh Ichsan Rifa'i. Organisasi ini bermarkas di Jl. Monginsidi III/1 Bojonegoro, persis di belakang masjid al-Mukhlisin, tempat pertama kali diadakan Madrasah Karbala. Mereka melakukan ritual Syiah secara rutin, misalnya, Doa Kumayl setiap malam Jumat dan Doa Tawasul setiap malam Rabu. Setiap selesai doa selalu diadakan diskusi terbuka. Lokasi pelaksanaannya berpindah-pindah dari satu tempat ke tempat lain, bahkan sesekali dilakukan di balkon alun-alun Kota Bojonegoro.

Penentangan masyarakat semakin mengeras. Anak-anak muda yang selama ini berkiprah di masjid al-Mukhlisin diberhentikan dari tugasnya. Akhirnya, acara Madrasah Karbala pada tahun 2004 tidak lagi bisa dilaksanakan di masjid al-Mukhlisin karena ditolak oleh para pengurus masjid. Acara akhirnya dipindah ke desa sebelah, tepatnya di halaman Kelurahan Klangon Bojonegoro.

Acara Madrasah Karbala kali ini tidak kalah hebohnya dengan acara setahun sebelumnya. Salah satu penceramah yang diundang adalah Djoko Susilo, tokoh Muhammadiyah yang saat itu menjadi anggota DPR RI. Panitia juga melakukan dialog terbuka secara on air di Radio Darussalam Bojonegoro. Perlu diketahui bahwa Radio Darussalam ini adalah milik Masjid Jami’ Darussalam Kota Bojonegoro, di mana penguasanya selama 
ini adalah para elite agama di Kota Bojonegoro (Ketua NU, Ketua MUI, Ketua Depag). Reaksi sangat keras datang dari tokoh-tokoh Islam Bojonegoro dengan cara menyegel Radio Darussalam (pintunya dipalang dan dipaku) dan memberhentikan seluruh operasional radio tersebut, termasuk memecat penyiarnya.

Puncak acara Asyura dilaksanakan di depan Masjid Jami Darussalam Kota Bojonegoro. Lokasi tersebut dipilih secara sengaja karena di tempat itulah setahun yang lalu kelompok Al-Bayyinat menyerang komunitas Syiah secara terbuka. ${ }^{27}$ "Aparat keamanan masjid" memaksa panitia agar memindahkan panggung ke lokasi lain, tapi panitia tetap bersikukuh, sebab lokasi panggung terletak di jalan raya, bukan wilayah masjid. Bahkan ada oknum Pemda Kabupaten Bojonegoro bersedia "membayar" sejumlah uang agar pelaksanaan acara dipindah ke tempat lain. Panitia tetap bergeming, sebab panggung sudah terlanjur berdiri, dan panitia sudah mendapatkan izin dari Polres Bojonegoro. Sekali lagi, acara tersebut dihadiri oleh KH. Said Agil Siraj.

Tak ayal, reaksi penentangan semakin keras. Sekalipun demikian, komunitas Syiah yang baru tumbuh ini tetap berjalan seperti apa adanya. Madrasah Karbala tetap dilaksanakan di tahun 2005 dengan lokasi di Aula Kelurahan Klangon Kota Bojonegoro, sedangkan puncak acaranya kembali dilaksanakan di alun-alun Kota Bojonegoro, tepatnya di depan Masjid Jami' Darussalam Bojonegoro. KH. Said Agil Siraj kembali hadir di acara puncaknya.

Penolakan masyarakat Bojonegoro, terutama yang ada di Desa Sukorejo semakin meningkat. Mereka meminta Ketua Takmir Masjid, H. Rohmat Munari, ayah Irfan Rifa'i, untuk mengusir para pengikut Syiah yang bermarkas di rumahnya. H. Rohmat Munari tidak bisa memenuhi tuntutan tersebut. Akhirnya diputuskan bahwa sejak saat itu anak-anak

27 Wawancara dengan Irfan Rifa'i, Ketua Branis Community, organisasi sosial pengikut Syiah Bojonegoro, dan Andik, 19 Mei 2016. 
muda pengikut Syiah tersebut dilarang untuk beraktivitas di Masjid alMukhlisin.

Hari-hari itu situasinya bisa dikatakan tegang hingga pihak kepolisian menurunkan seorang intel. Keberadaan intel ini baru diketahui setelah beberapa hari berkomunikasi intensif dengan anak-anak muda Syiah tentang ajaran Syiah. Intel dari Polwil Bojonegoro ini tidak melakukan tindakan represif apa pun terhadap komunitas Syiah ini, bahkan dia memberikan nomor kontaknya agar sewaktu-waktu bisa dihubungi apabila terjadi hal-hal yang dianggap mengganggu keamanan komunitas. Sejak itu, anak-anak muda Syiah ini merasa mendapatkan perlindungan dari pihak kepolisian.

Suatu ketika, markas komunitas Syiah (rumah H. Rohmat Munari) didatangi puluhan warga yang di koordinir oleh salah seorang tokoh agama setempat. Mereka melakukan "demonstrasi” menuntut agar semua orang yang mengikuti ajaran Syiah angkat kaki dari desa Sukorejo. Menghadapi situasi ini, mereka menghubungi aparat kepolisian. Aparat kepolisian datang dan langsung terlibat aktif dalam menyelesaikan masalah. Aparat kepolisian yang datang mencatat identitas para demonstran, kemudian membubarkan mereka dengan memperingatkan, bila terjadi lagi kekisruhan serupa di belakang hari, maka semua nama yang sudah diidentifikasi akan langsung diciduk ke Mapolwil Bojonegoro.

Demonstrasi selesai seketika itu juga. Sejak saat itu hingga sekarang, tidak pernah ada lagi ancaman kepada komunitas Syiah di Bojonegoro. Akan tetapi, berbagai peristiwa di atas membuat komunitas Syiah Bojonegoro bertindak lebih bijaksana demi menjaga kerukunan sesama. Meskipun saat ini para pengikut Syiah sudah tidak dilarang lagi memasuki masjid al-Mukhlisin, tapi mereka tetap menahan diri untuk tidak beraktivitas di masjid. Mereka membangun kebersamaan bersama warga melalui Grup Shalawat al-Banjari.

Sejak tahun 2008, komunitas Syiah ini mengorganisir diri dalam organisasi sosial yang bernama "Brains Community" dan terdaftar secara resmi di Bakesbangpol Bojonegoro. Melalui organisasi ini, mereka 
mengalihkan aktivitasnya dari masalah-masalah teologi ke sosial, terutama ke dunia pendidikan. Pada tahun 2009, mereka dipercaya Pemda Kabupaten Bojonegoro untuk menggarap peningkatan kualitas guru seKabupaten Bojonegoro melalui pelatihan "Multiple Intelligencey System". Selama dua tahun mereka dipercaya untuk meng-up grade kemampuan guru-guru dalam melakukan tugas-tugasnya di sekolah. Mereka juga membangun sebuah madrasah diniyah dengan kurikulum dan metode ala multiple intelligence system.

Saat ini, mereka tidak lagi sibuk dengan "perdebatan teologi" melawan kelompok berbeda mazhab. Menurut pengakuan ketuanya, relasi dengan pemerintah terutama dibangun untuk kerja pemberdayaan masyarakat. terutama di bidang pendidikan. Saat ini, melalui Brains Community, mereka lebih banyak melakukan aksi-aksi sosial. ${ }^{28}$

\section{Konflik Majelis Tafsir Alquran (MTA) Ngambon}

Kamis 16 Mei 2013, puluhan warga Desa Ngambon, Kec. Ngambon, Bojonegoro, berunjuk rasa di depan kantor Polsek Ngambon. Mereka menolak keberadaan Majelis Tafsir Alquran (MTA) di desanya karena dinilai menghina budaya setempat. Mereka meminta agar MTA tidak lagi melakukan aktivitas di desanya. Tidak hanya pihak kepolisian Polres Bojonegoro, Kepala Desa Ngambon, Camat Ngambon, dan Danramil turut mengondisikan unjuk rasa dan memahamkan masyarakat. ${ }^{29}$

Sebetulnya, konflik antara MTA dengan warga Desa Ngambon telah berjalan cukup lama. Keberadaan MTA Cabang Kecamatan Ngambon, Bojonegoro, sudah dimulai sejak tahun 1997/1998. ${ }^{30}$ MTA Cabang Ngambon Bojonegoro diketuai oleh Yulianto, dengan alamat di Jl. Raya Ngambon, Kec. Ngambon, Kabupaten Bojonegoro. ${ }^{31}$ Pada awalnya warga

\footnotetext{
28 Wawancara dengan Irfan Rifa'i, Ketua Branis Community, organisasi sosial pengikut Syiah Bojonegoro, dan Andik, 19 Mei 2016.

29 "Diduga Sesat, Warga Ngambon Demo Yayasan MTA," www.blokbojonegoro.com, diakses pada 14 Mei 2016.

${ }^{30}$ Wawancara melalui telepon dengan Siti Aminah, jamah MTA Ngambon sekaligus istri Hariyanto, Sekretaris MTA Cabang Ngambon, 16 Mei 2016.

31 www.mta.or.id, diakses pada 16 Mei 2016.
} 
tidak melakukan reaksi apa pun terhadap dakwah yang dilakukan MTA di desanya. Lambat laun, warga Ngambon merasa dakwah MTA menyinggung perasaan mereka. Sementara, pihak MTA sendiri merasa tidak pernah melakukannya. Kasus ini akhirnya memantik konflik yang berlarut-larut antara warga Ngambon dengan pengurus dan jamah MTA.

Pemkab Bojonegoro sendiri berdiri di posisi netral dengan memegangi hak-hak sipil yang dimiliki oleh MTA. Sebagaimana yang dinyatakan Kepala Bakesbangpol Bojonegoro, "Secara hukum, keberadaan MTA sah sehingga keinginan warga sekitar yang meminta MTA tidak ada di desanya tidak mungkin bisa dikabulkan." ${ }^{32}$

Menurut Bupati Bojonegoro, Suyoto, pemerintahannya harus berbuat netral dengan tidak masuk ke wilayah keyakinan. Netralitas negara dibuktikannya dengan memberi izin penggunaan alun-alun untuk aktivitas MTA sekalipun diirinya banyak diprotes warga lain. Menurutnya, penyebab penolakan warga terhadap MTA bukan pada keyakinan yang berbeda, namun cara berkomunikasi. Karena itu, yang ditekankan adalah membangun hubungan baik antar berbagai kelompok keyakinan yang berbeda. Hubungan baik sesama warga lebih penting dari sekedar izin negara karena sekalipun Bupati mengizinkan kegiatan MTA, kalau masyarakat menolak keberadaan mereka, konflik sosial akan tetap terjadi. ${ }^{33}$

Pandangan Bupati di atas sama dengan yang diutarakan Pihak Kejaksaan Bojonegoro. Menurut Kasi Intelijen Kejaksaan Negeri Bojonegoro, Nusirwan Sahrul, konflik MTA yang terjadi di Desa Ngambon disebabkan kurang nya komunikasi antar kedua belah pihak. Menurutnya, yang dibutuhkan kedua belah pihak adalah menghilangkan egoisme masing-masing sehingga tercapai kesepakatan. Jika kedua belah pihak saling menghargai, maka tidak akan terjadi permasalahan. Jika tidak

\footnotetext{
32 "Pemkab Dialogkan Konflik MTA," http://koran-madura.blogspot.co.id,, diakses pada 14 Mei 2016; "Pemkab Bojonegoro Gelar Dialog MTA dengan Warga," www.antarajatim.com, diakses pada 14 Mei 2016; "Pemkab Belum Temukan Fakta MTA Menyimpang," www.blokbojonegoro.com, diakses pada 14 Mei 2016.

33 "Wali Kota Bogor Bima Arya Dicoret dari Pejabat Pro-HAM," www.cnnindonesia.com, diakses pada 14 Mei 2016.
} 
memungkinkan, MTA tetap bisa melakukan kegiatan rutin di cabang kecamatan lain yang tidak menuai masalah. "Kedua belah pihak harus saling menghargai satu sama lain," ujarnya. ${ }^{34}$

Karena itu, maka yang ditempuh Pemerintah Kabupaten Bojonegoro adalah memediasi kedua belah pihak sebagai usaha menyelesaikan konflik. Pihak Muspika Kecamatan Ngambon secara aktif melakukan mediasi, sebelum ditindaklanjuti oleh Bakesbangpol Kabupaten Bojonegoro dengan menggelar beberapa putaran dialog di kantor Kabupaten.

Hasilnya adalah saling memahami kedua belah pihak. Di satu sisi, pemerintah Kabupaten Bojonegoro sama sekali tidak melakukan pelarangan atas keberadaan MTA yang memang sah berdasarkan undangundang. Kapolres Bojonegoro, AKBP Rakhmad Setyadi, secara tegas mengungkapkan bahwa MTA merupakan organisasi masyarakat resmi yang juga dilindungi undang-undang. Di sisi lain, pihak MTA memahami keberatan warga. Perwakilan MTA, Yulianto, menyatakan bahwa selama permasalahan ini belum selesai, MTA akan mengendapkan hati untuk tidak melakukan pengajian rutin terlebih dulu. Dia berharap ke depan bisa saling memahami dan saling memaafkan dengan warga Ngambon. "Kita berharap setelah ada pertemuan ini, warga sekitar dan anggota MTA bisa saling berjabat tangan. Sebenarnya antara warga dengan anggota MTA hanya miss komunikasi," tegas Yulianto. ${ }^{35}$

Hal senada disampaikan Hasan Basri dari FKUB Bojonegoro. Kalau masalah MTA malah sangat sederhana. Ketika kita dapat laporan ada penolakan warga tentang organisasi ini, ya kita datang, kemudian kita selesaikan dengan dialog. Sebenarnya warga Ngambon tidak menolak praktik ibadahnya, tapi karena menjelek-jelekkan praktik ibadah NU, sehingga kita agak repot untuk memahamkan kepada para ulama NU yang ada di sana. Kami juga harus membujuk MTA untuk tidak menggunakan

\footnotetext{
34 "MTA Ngotot, Enggan Pindah dari Ngambon," www.halobojonegoro.com, diakses pada 14 Mei 2016.

35 "MTA Diminta Tidak Melakukan Kegiatan," www.banyuurip.com, diakses pada 14 Mei 2016.
} 
masjid NU dalam melakukan kegiatan dakwahnya. Kalaupun toh menjelek-jelekkan praktik ibadah kami, maka jangan di [loud] speaker [karena] itu akan memicu orang-orang untuk melakukan tindakan. Tapi untungnya kemudian MTA juga mau memahami dan akhirnya selesai. Bahwa kemudian mereka tetap melaksanakan praktik ibadahnya, kita menyadari itu memang bagian dari hak yang harus dilindungi. Jadi, setiap ada konflik...di Bojonegoro bisa diselesaikan secara dialog. ${ }^{36}$

Setelah situasi kondusif dan terjalin saling pengertian, kini aktivitas MTA berjalan dengan lancar tanpa ada usikan dari kelompok yang berbeda. Pengajian rutin berjalan seperti semula. Masyarakat sekitar tidak ada lagi yang mengganggu. ${ }^{37}$

\section{Konflik Klenteng Hok Swie Bio: Peran Mediasi Negara dalam Konflik Internal Umat Beragama}

Kasus lain yang tidak kalah peliknya yang dihadapi Pemkab Bojonegoro adalah konflik internal kepengurusan pada Tempat Ibadah Tri Dharma (TITD) Klenteng Hok Swie Bio. Klenteng ini sendiri merupakan salah satu andalan tujuan pariwisata di Kota Bojonegoro. Klenteng ini merupakan tempat ibadah Tri Darma yang terkenal dengan ornamen kepala naganya. Klenteng ini banyak dikunjungi peziarah, terutama pada hari raya Imlek. Peziarah yang datang tidak hanya dari Bojonegoro, tapi juga dari daerah lain. ${ }^{38}$

Konflik ini melibatkan Tan Tjien Hwat dengan Go Kian An. Kasus dualisme kepengurusan ini muncul setelah adanya pemilihan ketua Yayasan TITD untuk masa bakti 2013-2015. Sekalipun Go Kian An kalah dalam pemungutan suara, namun dia ditunjuk menjadi ketua baru menggantikan Tan Tjien Hwat dan oleh formatur/panitia pemilihan pada

\footnotetext{
36 Wawancara dengan Hasan Bisri, Ketua KP LIMA FKUB Bojonegoro dan Tim Ahli Ketua DPRD Bojonegoro, 28 Mei 2016.

${ }^{37}$ Wawancara melalui telepon dengan Siti Aminah, jamah MTA Ngambon sekaligus istri Hariyanto, Sekretaris MTA Cabang Ngambon, 16 Juni 2016.

38 "Klenteng Hok Swie Bio, "http://www.bojonegorokab.go.id, diakses pada 14 Mei 2016.
} 
11 September 2013. Pelantikan ini memicu perpecahan di kalangan umat Klenteng Hok Swie Bio. ${ }^{39}$

Dalam perkembangannya, perseteruan ini melibatkan banyak pihak. Dalam hal kepengurusan, pihak Pengadilan Negeri Bojonegoro memenangkan Go Kian An sebagai pihak yang berhak mengatur, mengelola serta menjalankan kegiatan keagamaan di TITD Hok Swie Bio. Go Kian An yang merasa sebagai ketua Klenteng menggugat Tan Tjien Hwat yang dianggap menggelapkan aset Klenteng. ${ }^{40}$ Dalam putusannya, Majelis Hakim PN Bojonegoro menyatakan bahwa gugatan para penggugat dikembalikan pada perkara awal. Karena terjadi dissenting opinion, maka penggugat boleh mengajukan gugatan lagi dengan memperbaiki gugatannya sesuai dengan yang dipertimbangkan majelis hakim. ${ }^{41}$

Kasus hukum lain yang menyertai konflik kepengurusan ini adalah laporan perusakan kunci gudang Klenteng Hok Swie Bio oleh pendukung Tan Tjien Hwat. Mereka membuka paksa kunci kantor karena kunci lama diganti baru sehingga mereka tidak bisa masuk untuk mengambil peralatan liang-liong. Mereka akan latihan liang-liong sebagai persiapan Imlek bulan depan. Tapi karena semua ruangan dikunci, mereka kemudian membuka paksa kunci kantor. tidak bisa mengambil peralatan di dalam gudang. ${ }^{42}$

Sekali lagi, Bupati Bojonegoro, Suyoto, langsung turun tangan memimpin mediasi antar kedua kubu. Mediasi berlangsung pada Rabu, 22 Mei 2013 di Kantor Kabupaten Bojonegoro. ${ }^{43}$ Cara lain yang digunakan Bupati dalam mendamaikan kedua kubu adalah memfasilitasi perayaan Imlek 2014 di pendopo Kabupaten. Hadir kedua kubu yang sedang

\footnotetext{
39 "Vonis Aset Klenteng Hok Swie Bio Dissenting Opinion," www.beritajatim.com, diakses pada 14 Mei 2016.

40 "Kasus Kelenteng Hok Swie Bio Disidangkan," www.suarabanyuurip.com, diakses pada 14 Mei 2016.

41 "Vonis Aset Klenteng Hok Swie Bio Dissenting Opinion," www.beritajatim.com, diakses pada 14 Mei 2016.

42 "Kasus Klenteng Bojonegoro Lanjut ke Ranah Pidana," www.beritajatim.com, diakses pada 14 Mei 2016.

43 "Mediasi konflik Klenteng Berlangsung Alot," www.blokbojonegoro.com, diakses pada 14 Mei 2016.
} 
bersengketa. Dalam sambutannya, Bupati mengajak masyarakat Tionghoa bersatu mengamalkan semboyan Bbineka Tunggal Ika. Bupati sendiri sama sekali tidak ingin memihak pada salah satu kubu karena menurutnya yang harus menyelesaikan sengketa adalah warga Klenteng sendiri. ${ }^{44}$

Konflik terus berlarut-larut. Pendukung Tan Tjien Hwat melakukan aksi demo di halaman Pengadilan Negeri Bojonegoro karena Ketua Pengadilan Negeri mengeluarkan putusan memenangkan kepengurusan Go Kian An. Menurut pendukung Tan Tjien Hwat, Go Kian An merupakan calon ketua yang kalah dalam pemilihan namun dilantik, sedangkan Tan Tjien Hwat yang mendapat suara terbanyak justru tidak dilantik. Menurut pendukung Tan Tjien Hwat, mediasi yang dilakukan oleh Bupati juga dinilai gagal karena Bupati tidak mampu menyelesaikan sengketa, namun hanya penengah. ${ }^{45}$

Sampai tahun ini pun konflik sesungguhnya belum usai. Konflik semakin pelik ketika masa jabatan Go Kian An habis pada Desember 2015, sedang salinan putusan MA yang memenangkan Go Kian An belum diterima. Dalam situasi ini, ada unsur umat yang secara sepihak membentuk panitia pemilihan ketua. Kali ini konflik melibatkan Go Kian An dengan Hadi Sugiarto yang mengaku sebagai Ketua Pembentukan Panitia Pemilihan. Pihak Hadi Sugiarto mengirim undangan kepada umat Klenteng untuk mengikuti musyawarah umat sekaligus pemilihan ketua TITD Hok Swie Bio Bojonegoro periode 2016-2019 pada hari Minggu tanggal 27 Maret 2016 di gedung pertemuan Tri Dharma. ${ }^{46}$ Go Kian An merasa keberatan atas panitia yang mengatasnamakan umat tersebut karena dianggap tidak sesuai dengan AD/ART Organisasi tentang proses pemilihan pengurus baru.

\footnotetext{
44 "Konflik Klenteng Masih dalam Proses Penyelesaian," www.blokbojonegoro.com, diakses pada 14 Mei 2016.

45 "Umat TITD Sebut Bupati Tak Becus," www.halobojonegoro.com, diakses pada 14 Juni 2016.

46 "Rencana Pemilihan Ketua Klenteng Bojonegoro Diprotes," blokbojonegoro.com, diakses pada 14 Juni 2014.
} 
Di samping itu, masalah kepengurusan Klenteng masih menunggu salinan putusan dari Mahkamah Agung. Sementara itu, pihak yang mengatasnamakan panitia pemilihan ketua berdalih bahwa pemilihan ketua dilakukan atas dasar desakan umat karena jabatan Go Kian An sudah habis pada Desember 2015. Dengan kekosongan kepengurusan di TITD Hok Swie Bio Bojonegoro, maka diwacanakan pembentukan panitia pemilihan bersama. ${ }^{47}$

Tentu saja, masing-masing kubu bertahan dengan argumennya masing-masing. Pihak panitia pemilihan berdalih kekosongan jabatan ketua, sedang pihak Go kian An merasa bahwa pihaknyalah yang berhak membentuk kepanitiaan. Keberatan Go Kian An bisa dimaklumi karena Putusan Perdata Nomor 604/PDT/2014/Pt SBY dalam perkara antara TITD Klenteng Hok Swie Bio melawan Tan Tjien Hwat beserta jajaran kepengurusannya dimenangkan Go Kian An. Perkara ini sudah diputuskan oleh Pengadilan Tinggi Surabaya tertanggal 5 Februari 2015, dengan menolak eksepsi para tergugat dan turut tergugat seluruhnya. Hasil putusan PT Surabaya, menyebutkan Gandhi Koesmianto alias Go Kian An sah sebagai Ketua atau pengurus terpilih TITD. Keputusan ini juga dikuatkan putusan dari Mahkamah Agung dengan Nomor Putusan 2746 K/PDT/2015. ${ }^{48}$

Sekalipun konflik Klenteng hingga sekarang belum selesai seluruhnya, namun ada hal penting yang perlu dicatat. Pihak pemerintah terus melakukan mediasi dan tetap menempatkan dirinya sebagai wasit netral dalam konflik internal tersebut. Seluruh sengketa di dalam internal umat Klenteng Hok Swie Bio didorong untuk diselesaikan di antara mereka sendiri, baik melalui musyawarah maupun melalui mekanisme peradilan, sedang pihak pemerintah hanya melakukan fungsi-fungsi mediasi agar

\footnotetext{
47 "Forpimda Bojonegoro Lakukan Mediasi Kepada Kedua Kubu Terkait Kemelut Klenteng TITD," www.metropantura.com, diakses pada 14 Juni 2016.

48 "Dualisme Klenteng Hok Swie Bio Memanas Lagi," www.beritametro.co.id, diakses pada 14 Juni 2016.
} 
konflik dualisme kepengurusan tidak berujung pada konflik sosial yang destruktif.

\section{Kultur-Keagamaan yang Moderat dan Kehidupan Sosial yang Guyub}

Menurut Agustino, agama menjadi salah satu sumber konflik penting di samping hubungan darah, ras, adat, wilayah, dan bahasa. ${ }^{49}$ Penelitian Karnaji tentang konflik dan upaya perdamaian di Jawa Timur menemukan bahwa konflik horizontal atau konflik identitas yang berlatarbelakang isu SARA adalah konflik yang paling potensial meledak di Jawa Timur. Isu Kristenisasi, pelarangan pembangunan gereja, prasangka antarkelompok pemeluk agama yang berbeda adalah beberapa hal yang sering muncul di berbagai daerah di Jawa Timur dalam lima tahun terakhir. ${ }^{50}$

Studi Karnaji juga menemukan bahwa ada pranata sosial dan kearifan lokal di beberapa wilayah di Jawa Timur yang secara efektif berfungsi meredam agar perbedaan dan potensi konflik tidak meletup menjadi konflik yang terbuka. Pada sebagian masyarakat memang ditemukan secara kuat adanya prasangka yang membuat kelompok-kelompok berbeda keyakinan bisa melahirkan konflik terbuka, namun pada sebagian masyarakat ditemukan ada nilai-nilai dan praktik-praktik sosial-budaya yang membuat mereka mampu mengelola perbedaan sehingga sanggup membangun kehidupan sosial yang toleran. ${ }^{51}$

Salah satu faktor yang menentukan dalam membangun kehidupan sosial yang harmonis di tengah perbedaan sosial yang ada adalah apa yang disebut cross-cutting affiliation, yaitu sebuah zona interaksi sosial netral di mana antarkelompok yang berbeda tetap dapat saling berhubungan tanpa dibayang -bayangi oleh berbagai identitas kelompok yang membuat mereka memandang kelompok lain sebagai 'sang liyan'. ${ }^{52}$ Zona netral ini

${ }^{49}$ Leo Agustino, "Konflik dan pembangunan politik," Analisis, CSIS, Vol. 33, No. 3 (2004), 171-182.

${ }^{50}$ Karnaji, dkk., "Social Early Warning System."

${ }^{51}$ Ibid.

52 Ibid. 
bisa berupa hubungan ekonomi, ekonomi maupun praktik-praktik sosial yang lain.

Praktik seperti ini bekerja dengan baik di Bojonegoro. Komunitas Syiah yang awalnya berseteru dengan warga Sunni karena dakwahdakwahnya yang provokatif, yang sengaja memamerkan perbedaan ajaran dengan kelompok Sunni, pada akhirnya menggeser kiprahnya ke arah kerja-kerja sosial tanpa dimuati dengan jargon-jargon teologis. Sementara, FKUB Kabupaten Bojonegoro menciptakan berbagai model interaksi sosial lintas iman melalui berbagai aktivitas bersama tanpa embel-embel agama, misalnya, lomba menulis atau olahraga yang menjangkau siswasiswa SLTA atau mahasiswa. ${ }^{53}$

Secara umum, masyarakat Bojonegoro menekankan pada nilai-nilai guyub, rukun, dan selamet bersama. Hampir semua informan, dari berbagai latar belakang keyakinan, profesi, dan lapis sosialnya, menyatakan bahwa secara kultur, masyarakat Bojonegoro adalah masyarakat yang rukun dan damai karena situasi itulah yang memungkinkan mereka untuk bisa membangun perekonomiannya.

Sebagaimana yang diungkapkan salah seorang anak muda pengikut Syiah. Menurutnya, "Di Bojonegoro ini ada kesadaran, yang penting rukun dan damai, karena dengan itu, kita bisa bekerja dan mencari uang dengan enak." 54 Pandangan yang persis sama diungkapkan oleh Ketua PCNU Bojonegoro, "Wong hidup rukun aja susah mencari makan, apalagi kalau tidak rukun, apa tidak susah. ${ }^{" 55}$ Karena itu, menurut Hasan Basri (FKUB), "Di Bojonegoro [tugas FKUB] tidak merukunkan, tapi merawat kerukunan itu sendiri karena kerukunan masyarakat di Bojonegoro sudah terjadi sekian lama. ${ }^{56}$

\footnotetext{
53 Wawancara dengan Hasan Bisri, Ketua KP LIMA FKUB Bojonegoro dan Tim Ahli Ketua DPRD Bojonegoro, 28 Mei 2016.

${ }^{54}$ Wawancara dengan Irfan Rifa'i, Ketua Branis Community, organisasi sosial pengikut Syiah Bojonegoro, dan Andik, 19 Mei 2016.

${ }_{55}$ Wawancara dengan dr. Kholid Ubed, Ketua PCNU Bojonegoro, 1 Juni 2016,

${ }^{56}$ Wawancara dengan Hasan Bisri, Ketua KP LIMA FKUB Bojonegoro dan Tim Ahli Ketua DPRD Bojonegoro, 28 Mei 2016.
} 
Sebagian besar masyarakat Bojonegoro bukanlah kaum agamais. Kalaupun ada yang masuk dalam kategori santri, sebagian besar mereka bukan orang yang sangat fanatik. Karena itu, isu agama tidak menjadi isu penting bagi masyarakat Bojonegoro secara umum. Hal ini dinyatakan sendiri oleh Ketua PCNU Bojonegoro, "Dari dulu memang begitu karakter masyarakat Bojonegoro. Yang paham banget agama ya ndak ada, yang gak paham banget justru yang banyak. Jadi ya begitulah, gimana menggambarkannya. ${ }^{, 57}$

Kesadaran untuk hidup rukun dikombinasi dengan tidak menjadikan agama sebagai kesadaran penting dalam kehidupan sosialnya membuat masyarakat Bojonegoro memiliki kekenyalan dalam menghadapi provokasi pihak luar untuk melakukan tindakan-tindakan kekerasan berbasis keyakinan.

Pernyataan tersebut dibenarkan oleh Mazroi, sekretaris PCNU Bojonegoro. Menurutnya, kelompok-kelompok radikal di luar Bojonegoro tidak berhasil mendapatkan dukungan dari masyarakat Bojonegoro ketika mereka mencoba masuk.

"Kelompok-kelompok radikal itu berada di luar Bojonegoro. Ketika mereka masuk untuk memengaruhi sebagian masyarakat di Bojonegoro, [sedang] masyarakat Bojonegoro karakternya acuh karena disibukkan dengan kegiatan-kegiatan ekonomi, ya akhirnya tidak bisa berkembang." "58 "Daerah sini, masyarakatnya tergolong cuek. Perbedaan pemahaman tidak mudah menyulut kami untuk melakukan tindakan-tindakan penyerangan seperti di daerah lain." 59 "Kalu mengenai masyarakat tidak tergerak [oleh provokasi pihak luar], memang mungkin karena kultur masyarakat sini itu cuek terhadap keyakinan ya. Kan sejarahnya, masyarakat sini itu pelarian dari Majapahit dan Pajajaran. Mereka cenderung orang yang mempunyai kultur mengedepankan saling membantu dan tidak mau ikut menghakimi keyakinan atau urusan orang. Ini memang secara karakter berbeda dengan masyarakat di luar Mataraman. Kan kita ini

\footnotetext{
${ }^{57}$ Abdul Wahid (Tokoh Kultural Muhammadiyah, Pengasuh Panti Asuhan dan Pemilik Rumah Makan Hatmi), wawancara, 31 Mei 2016.

${ }^{58}$ Wawancara dengan Mazroi, Sekretaris PCNU Bojonegoro, 25 Mei 2016.

${ }^{59}$ Wawancara dengan Irfan Rifa'i, Ketua Branis Community, organisasi sosial pengikut Syiah Bojonegoro, dan Andik, 19 Mei 2016.
} 
memang Mataraman. Tidak seperti daerah Tapal Kuda atau Madura yang cenderung reaksioner. Kita ini sudah disibukkan dengan mencari kehidupan ekonomi sehingga untuk terprovokasi pun sangat rendah." ${ }^{60}$

"Begini, secara kultur, masyarakat Bojonegoro ini berbeda dengan masyarakat yang cenderung mudah terprovokasi. Masyarakat Bojonegoro ini kan berada di kawasan tengah yang cenderung tidak keras seperti masyarakat di daerah pesisir, seperti Lamongan dan daerah Tapal Kuda. Masyarakat sini sudah disibukkan untuk mencari ekonomi daripada melakukan tindakan-tindakan untuk berkonflik, terlebih atas nama agama. Mereka lebih disibukkan dengan kegiatankegiatan ekonomi, berdagang, bersawah dan lain sebagainya."61

Karena itulah, maka hampir tidak ditemukan adanya gerakan-gerakan keagamaan radikal di Bojonegoro. Bisa dikatakan, Bojonegoro adalah tanah gersang bagi tumbuhnya kelompok-kelompok keagamaan eksklusif/radikal yang mudah menyalahkan kelompok lain, apalagi dengan sengaja membangun konflik dengan kelompok berbeda. Memang ada riakriak konflik antar keyakinan, namun masyarakat umum cenderung tidak bersimpati karena tidak sejalan dengan nilai-nilai budaya yang dianutnya. ${ }^{62}$ MTA bisa hidup di Bojonegoro ketika mereka tidak lagi mengolok-olok kelompok lain dalam dakwahnya. FPI sempat ada, namun tidak berkembang dan akhirnya mati seiring dengan kematian para tokohnya. HTI juga sempat melakukan deklarasi, namun hingga sekarang tidak terdengar kiprahnya. ${ }^{63}$

${ }^{60}$ Wawancara dengan Hasan Bisri, Ketua KP LIMA FKUB Bojonegoro dan Tim Ahli Ketua DPRD Bojonegoro, 28 Mei 2016.

${ }^{61}$ Wawancara dengan Mazroi, Sekretaris PCNU Bojonegoro, 25 Mei 2016.

62 "Kalau gerakan radikalisme itu gak ada kayaknya di Bojonegoro. Dulu memang ada, tapi ndak berkembang. [Hal itu] karena memang masyarakat acuh terhadap [isu-isu] keagamaan, dan sering kali dianggap gak begitu penting gerakan-gerakan itu." (Wawancara dengan Hasan Bisri, Ketua KP LIMA FKUB Bojonegoro dan Tim Ahli Ketua DPRD Bojonegoro, 28 Mei 2016.).

${ }^{63}$ Ketika HTI mengadakan deklarasi pada Sabtu 30 April 2016, Gerakan Pemuda (GP) Ansor Cabang Bojonegoro menggelar apel bela negara untuk menolak keberadaan HTI di Bojonegoro. Ketua Ansor Bojonegoro, Abdullah Faizin menegaskan, menegaskan bahwa pihaknya menolak segala gerakan dan aktivitas HTI di kotanya, termasuk acara deklarasi yang dilaksanakan di Gedung Serbaguna, Bojonegoro. Sementara, ketua HTI Bojonegoro, Antok Lutfi Yulianto menyatakan tetap akan menggelar acaranya karena sudah mendapatkan izin dari aparat kepolisian. Keinginan Banser untuk menggagalkan 
"Kalau di Bojonegoro, gerakan radikalisme tidak ada mas setahu saya. Mungkin ada, tapi tidak bisa berkembang. Kemarin memang ada acara HTI yang melaksanakan tabligh akbar itu, tapi kemudian temanteman Ansor memprotes ke kepolisian. Setelah itu ya selesai, dan sampai sekarang tidak terdengar lagi. [Di sini juga] gak ada FPI. Dulu sih saya pernah dengar, lama, tapi akhir-akhir ini juga hilang dengan sendirinya." ${ }^{\prime 64}$

Peran tokoh agama juga tidak kalah pentingnya dalam membangun kehidupan keagamaan yang harmonis. Dalam membina umatnya, figurfigur yang berpengaruh sangat krusial karena melalui pesan yang mereka sampaikanlah umat akan menginternalisasi ajaran agama yang dipeluknya. Tokoh agama yang otoritatif dan legitimate di mata masyarakat bisa menjadi faktor penting karena menyangkut penerimaan dan pengakuan. Kualifikasi lain yang perlu dimiliki tokoh agama adalah jaringan, kharisma, dan kemampuan dalam mengarahkan kesadaran dan menyelesaikan konflik. Sebagai tokoh yang disegani dan dihormati masyarakat, posisi tokoh masyarakat dan ulama ibaratnya adalah sebagai pemadam kebakaran yang dengan taktis mampu mencegah kebakaran yang meluas sebelum api membesar. ${ }^{65}$

Sebagian besar tokoh-tokoh agama yang berpengaruh memiliki paham keislaman moderat. Bukan berarti bahwa di Bojonegoro tidak ditemukan figur-figur yang memiliki pandangan sebaliknya. Ada beberapa figur yang menginginkan berlakunya syariat Islam dengan menjadikan Aceh sebagai wilayah idaman. Mereka juga menyetujui melakukan amar makruf nahi munkar dengan melakukan tindakan langsung kepada orangorang yang dianggap berbuat kemungkaran. Kelompok ini juga tidak menginginkan keberadaan kelompok-kelompok minoritas yang memiliki keyakinan dan praktik keagamaan yang berbeda dari mainstream. Bahkan

acara berhasil dicegah oleh Ketua PCNU Bojonegoro. Akhirnya, acara bisa dilaksanakan pada Minggu, 1 Mei 2016 dengan pengawalan kepolisian secara ketat. (Wawancara dengan Wahroni, Kepala Dakwah HTI Bojonegoro, 3 Juni 2016; Wawancara dengan dr. Kholid Ubed, Ketua PCNU Bojonegoro, 1 Juni 2016).

${ }^{64}$ Wawancara dengan Mazroi, Sekretaris PCNU Bojonegoro, 25 Mei 2016.

${ }^{65}$ Karnaji, dkk., "Social Early W arning System." 
mereka sangat tidak respek dengan keberhasilan Bupati Suyoto yang berhasil membuat Bojonegoro sebagai Kabupaten ramah HAM. ${ }^{66}$

Sekalipun demikian, suara dan pengaruh mereka sangat tidak signifikan jika dibanding dengan kelompok moderat, baik dari kalangan NU maupun Muhammadiyah. Bupati Suyoto sendiri adalah tokoh penting dalam tubuh Muhammadiyah Bojonegoro. Di samping itu, tidak sedikit tokoh-tokoh Muhammadiyah yang memiliki pandangan keislaman moderat dan menjalin hubungan sangat baik dengan kelompok lain melalui berbagai kegiatan sosial yang dimilikinya.

Hal ini bisa dilihat pada sosok Abdul Wahid, salah satu pemilik rumah makan di Bojonegoro. Dia memiliki perhatian tinggi terhadap pendidikan anak-anak tidak mampu. Ilmu agamanya ia dapatkan dari Pesantren Modern Gontor. Dia adalah salah satu tokoh Muhammadiyah Bojonegoro, sekalipun tidak masuk dalam struktur kepengurusan Muhammadiyah Cabang Bojonegoro. Menurutnya,

"Orang beragama itu harus rukun agar kita bisa beribadah dengan tenang. .... Jihad itu kan mengajak kepada kebaikan, tapi tidak dengan kemungkaran, mengajak ke Jalan Allah dengan kebaikan. Dan jihad cara yang baik itu banyak sekali, misalnya dengan membantu orangorang, membantu pendidikan anak-anak.... Agama itu kan untuk kebaikan." ${ }^{67}$

Dia bahkan mengkritik beberapa kawan Muhammadiyah nya yang cenderung eksklusif.

"Kalau saya memang menjalin kerjasama dengan mereka [kelompokkelompok berbeda keyakinan], jadi tidak menutup pintu kerja sama seperti yang dilakukan oleh teman-teman lain di Muhammadiyah. ...saya kerja sama dalam bidang mengentaskan anak-anak [tidak mampu] ini agar mampu untuk kuliah. .... Jadi kalau memang selama berhubungan dengan orang-orang non-Islam, ya yang penting gak

\footnotetext{
66 Wawancara dengan Ikhwadun (pengurus FKUB dan tokoh Muhammadiyah), Tri Wibowo (Ketua DPC PKS), Munawir (HTI), Diah Kurniawan (Ketua HMI), dan Ilham Wahyudin (Ketua KAMMI), 28 Mei 2016.

${ }^{67}$ Abdul Wahid (Tokoh Kultural Muhammadiyah, Pengasuh Panti Asuhan dan Pemilik Rumah Makan Hatmi), wawancara, 31 Mei 2016.
} 
sampai menyangkut akidah, akan baik-baik saja. .... Nah saat saya mencari [dana] saya juga ndak memandang ini sesama Islam atau bukan, wong kadang sama-sama Islam ya maaf mas, tapi jauh lebih pelit. Yang penting kita amanah ya selesai."

Sementara, dari kalangan NU, sekalipun beberapa konflik keagamaan melibatkan warganya di tingkat bawah, seperti konflik dengan Syiah, MTA, Gereja Bethany, dan HTI, namun tokoh-tokoh NU yang berpengaruh memiliki pandangan yang mapan tentang toleransi dan kehidupan sosial yang rukun dan damai. ${ }^{69}$ Pandangan ini mereka bangun di bawah payung penerimaan atas NKRI sebagai negara yang di dalamnya ada sekian banyak keragaman warganya.

Pandangan ini, setidaknya membawa kepada dua konsekuensi berikutnya. Pertama, mereka menolak syariat Islam diformalisasi sebagai Perda.

"Saya kira, kalau hanya sebatas masukan ndak apa, tapi kalau [Syariat Islam] sampai dijadikan Perda [itu saya tidak setuju], karena masyarakat kita tidak hanya umat Islam. Bagaimana dengan agama lain? Itu satu. Yang kedua, dengan diberlakukan begitu, potensi besar konflik antar agama justru tidak bisa dibendung, misalnya, jika agama ini disetujui, kemudian agama lain gak disetujui, nah pasti konflik. Ya harusnya kita menghindari itu lah. UUD kita dan Pancasila sudah menurut saya cukup mewakili semua nilai-nilai agama."

Konsekuensi kedua adalah menolak segala kekerasan agama baik atas nama jihad maupun amar makruf nahi munkar sebagaimana yang dilakukan oleh kelompok-kelompok radikal.

"Jihad itu tidak masuk kalau dikaitkan dengan radikalisme. Jihad itu memang menegakkan agama Allah, tapi dengan cara-cara yang tidak

${ }^{68}$ Ibid.

${ }^{69}$ Ketua PCNU Bojonegoro mengakui bahwa banyak warganya yang mulai keluar dari koridor Moderatisme NU. "Di sinilah mas sebenarnya tugas saya, [yaitu] meng-NU-kan orang NU.... Kita itu sebagai orang NU didik dengan nilai-nilai moderat, tasâmuh, tawẫzun, ta'âdul, itu sudah mulai luntur. Kebanyakan mereka cenderung melakukan tindakantindakan atau sikap yang bisa dikatakan mulai keluar dari khițah NU-nya, sedikit-sedikit kalau tidak dilaksanakan, kia akan melakukan tindakan." (Wawancara dengan dr. Kholid Ubed, Ketua PCNU Bojonegoro, 1 Juni 2016).

${ }^{70}$ Ibid. 
memaksa, juga harus dilihat atau dipertimbangkan antara manfaat dan mudhlorot-nya. Kalau semua atas nama agama dipaksakan, ya agama tidak lagi menjadi rab\}matan li al-álamîn, tapi menjadi penebar kesengsaraan." 71

Begitu juga dalam amar makruf nahi munkar, mereka tidak bisa menerima penggunaan kekerasan. Bagi mereka, tindakan represif itu merupakan kewenangan negara. Tokoh agama hanya memiliki kewenangan sebatas dakwah dengan lisan. Di samping itu, penggunaan kekerasan atas nama amar makruf nahi munkar dianggap mengingkari keberadaan Indonesia yang mempunyai peraturan dan undang-undang sendiri, di mana warga negara tidak boleh melanggarnya. Umat Islam bukanlah satu-satunya kelompok yang hidup di Indonesia, tapi ada pemeluk agama lain yang memiliki hak-hak politik yang sama. ${ }^{72}$

Sampai di sini bisa dinyatakan bahwa dari aspek nilai-nilai budayakeagamaan, masyarakat Bojonegoro memiliki ketahanan dalam mempertahankan kehidupan keagamaan yang harmonis dan damai karena disokong, setidaknya, oleh dua hal. Pertama, kultur masyarakat Bojonegoro sendiri menekankan pada nilai-nilai keguyuban dan kerukunan. Di samping itu, secara umum, mereka bukanlah masyarakat yang menjadikan isu agama sebagai sesuatu yang penting dalam kehidupan sehari-harinya. Kedua, di kalangan masyarakat santri, nilai-nilai keagamaan yang terlembagakan adalah ajaran keagamaan yang moderat. Moderatisme ajaran agama (Islam) ini dipegang oleh tokoh-tokoh yang berpengaruh, disosialisasikan kepada umatnya, dan sejauh mungkin dijadikan pemandu dalam menciptakan kehidupan keagamaan yang damai tanpa konflik.

${ }^{71}$ Ibid.

72 Wawancara dengan dr. Kholid Ubed, Ketua PCNU Bojonegoro, 1 Juni 2016; Wawancara dengan Mazroi, Sekretaris PCNU Bojonegoro, 25 Mei 2016. 


\section{Negara sebagai Wasit Netral dan Tegas}

Dalam studi-studi perdamaian, salah satu faktor penting dalam meredam konflik komunal adalah adanya regulasi dan ketegasan aparatus negara yang mampu menetralisir konflik. ${ }^{73}$ Dalam konteks Kabupaten Bojonegoro, tiga kisah di atas menggambarkan secara kuat hadirnya negara dalam peristiwa-peristiwa sosial-keagamaan yang memiliki potensi kuat melahirkan konflik komunal. Kehadiran negara diwujudkan dalam bentuk netralitas dan ketegasan aparat serta upaya-upaya mediasi yang memungkinkan sebuah perselisihan bisa diselesaikan. Pihak pemda melalui Bakesbangpol bersama dengan aparat kepolisian, kejaksaan, FKUB secara aktif memediasi dan mencarikan jalan keluar dalam skema win-win solution.

Peristiwa perselisihan pengajian MTA dengan warga desa Ngambon, misalnya, adalah contoh jelas kehadiran pemerintah dalam memediasi sehingga kedua belah pihak merasa tidak dirugikan. Contoh lain adalah penolakan warga terhadap pendirian Gereja Bethany. Sebagaimana yang diceritakan Hasan Bisri,

"Itu kejadian sejak 2002. Saat ditanya oleh pengurus FKUB, dulu izinnya dibuat kantor sekretariat gereja dan rumah pendeta. Kemudian lambat laun, tempat itu juga digunakan untuk beribadah.... Karena masyarakat sekitar merasa terganggu, mereka ditolak. .... Kemudian kita [FKUB] fasilitasi dialog, kira-kira apa permasalahannya, kemudian kita cari solusi bersama-sama. .... Pemerintah waktu itu menunjuk kami dan Kesbangpol untuk memfasilitasi dialog tersebut. Kesbangpol...selalu turun untuk mendekati orang-orang yang menolak atau pihak Bethany. .... [Dalam dialog], tuntutannya, selesaikan persyaratan perizinannya dan tidak boleh di situ saja. Kemudian, pihak Bethany kita bujuk untuk mengiyakan dan pihak Kesbangpol membantu proses menyelesaikan perizinan. [Sekarang] sudah berdiri dengan megah di Jalan

${ }^{73}$ Karnaji, dkk., "Social Early Warning System." 
Sawunggaling, nomor 113, Kota Bojonegoro. Dan sekarang tidak ada permasalahan." 74

Netralitas dan ketegasan pimpinan politik atau aparatus negara secara umum diperlihatkan melalui ketidaktundukan pada desakan kelompok tertentu, sekalipun mungkin kelompok itu adalah mayoritas. Ketegasan aparat polisi dalam mengamankan komunitas Syiah, netralitas pemerintah dalam menyelesaikan kasus MTA adalah contoh konkret kehadiran negara sebagai wasit yang netral dan tegas. Bahkan, sekalipun banyak elemen yang menentang acara HTI, namun pihak kepolisian tetap memberi pengamanan yang proporsional untuk menjaga kemungkinan terjadinya konflik terbuka dengan pihak penentang. Khusus untuk MTA, apa yang dinyatakan oleh Amrozi, Humas Bakesbangpol Bojonegoro menunjukkan netralitas negara dalam menghadapi sengketa warganya. Menurutnya, "Kami tidak akan melakukan pembekuan atau melarang keyakinan MTA selama pemerintah pusat tidak membekukan organisasi tersebut. Bahwa kemudian kita diminta untuk melindungi keamanan mereka, ya sejauh kita lakukan sejauh kita mampu, sekalipun jika didesak dari mayoritas" ${ }^{\text {"75 }}$

Dalam studinya tentang tumbuhnya pluralisme dalam sebuah pemerintahan demokratis, Trigg menyatakan, "If people are to live freely in a democratic society, in which all citizen can contribute to discussion about the common good, they must be free to make up their own minds on where the common good may lie. ${ }^{76}$ Pandangan Trigg di atas merupakan pandangan umum bagaimana sebuah sistem politik demokratis harus memberi ruang bagi setiap pandangan untuk terlibat dalam memberi kontribusi tentang apa yang disebut dengan kebaikan bersama.

Seseorang bisa membuat asumsi bahwa setiap keyakinan agama, bahkan setiap nurani manusia, pada dasarnya mengajarkan tentang kebaikan dan hidup bersama dengan orang lain dalam sebuah tata

\footnotetext{
${ }^{74}$ Wawancara dengan Hasan Bisri, Ketua KP LIMA FKUB Bojonegoro dan Tim Ahli Ketua DPRD Bojonegoro, 28 Mei 2016.

${ }^{75}$ Wawancara dengan Amrozi, Humas Kesbangpol, 25 Mei 2016.

${ }^{76}$ Roger Trigg, Religious Diversity: Philosophical and Political Dimensions (New York: Cambridge University Press, 2014), 11.
} 
kehidupan yang baik. Tapi kita tidak bisa menutup mata bahwa terlalu banyak cerita di mana kebaikan yang dirumuskan oleh penganut keyakinan keagamaan tertentu, yang diyakini benar dan baik, ketika dipaksakan untuk berlaku secara umum, tidak menghasilkan apa pun kecuali konflik sosial yang parah. Konflik sosial yang diakibatkan oleh dominansi sebuah keyakinan tertentu bisa jadi tidak semata-mata karena secara objektif tidak membawa kepada kebaikan, namun hal itu berarti menutup partisipasi warga negara yang akhirnya melahirkan kecemburuan dan ketidakpercayaan.

Di sini yang perlu dipertimbangkan juga adalah proses bagaimana sebuah nilai-nilai yang dianggap sebagai baik dan akan diperlakukan di ruang publik melibatkan semua elemen warga negara sehingga apa pun yang pada akhirnya berlaku sebagai kebaikan bersama adalah buah dari kesepakatan demokratis. Kebaikan bersama pada akhirnya bukan sebuah pandangan yang semata-mata diasumsikan, namun dimiliki bersama karena setiap kelompok merasa menyumbang dan memiliki rumusan kebaikan bersama yang diterapkan di ruang publik. Demokrasi selalu mendambakan manusia yang kritis, rasional, dan toleran. ${ }^{77}$

Untuk mencapai situasi ini, dibutuhkan netralitas negara. Jika dikerucutkan, maka bisa dinyatakan bahwa dibutuhkan seorang pemimpin politik yang dapat mengatasi fanatisme primordial sehingga keberadaannya bisa diterima oleh semua pihak. Jika netralitas negara diyakini sebagai salah satu faktor penting dalam mendistribusikan keadilan (dan dengan sendirinya menciptakan perdamaian) warganya, ${ }^{78}$ maka setidaknya potret inilah yang bisa dilihat di Bojonegoro.

Untuk membuka kanal partisipasi seluas-luasnya, Bupati Bojonegoro menciptakan dua terobosan. Pertama, membuka pengaduan online melalui

77 M. Fadjroel Rahman, "Demokrasi: Perjuangan Menegakkan Kedaulatan Rakyat, dan Masyarakat Sipil yang Toleran-kritis-Rasional," dalam Larry Diamond (ed.), Revolusi Demokrasi: Perjuangan untuk Kebebasan dan Pluralisme di negara sedang Berkembang, ter. Matheos Nalle (Jakarta: Obor, 1994), xvii.

${ }^{78}$ Untuk bahasan tentang pluralisme dan keadilan, baca David Miller \& Michael Walzer (ed.), Pluralism, Justice, and Equality (New York: Oxford University Press, 1995). 
kanal Bojonegoro, di mana setiap warga Bojonegoro bisa mengadukan persoalannya atau menyampaikan aspirasinya, yang kemudian segera mendapatkan jawaban. Kedua, setiap habis salat Jumat sampai sekitar pukul 4 sore, Bupati membuka dialog terbuka dengan warga. Siapa saja bisa menyampaikan aspirasinya secara langsung.

Dalam hal kehadiran negara dalam menyelesaikan konflik sosial, Amrozi mengakui bahwa manfaat yang sangat bisa dilihat adalah mencegah potensi konflik menjadi aktual atau mendeeskalasi konflik agar tidak membesar tak terkontrol. ${ }^{79}$ Berdasarkan pertimbangan ini, Bakesbangpol Bojonegoro membentuk dan memfungsikan FKDM (Forum Kewaspadaan Dini Masyarakat) secara maksimal. FKDM merupakan instrumen yang digunakan pemerintah Bojonegoro untuk mendeteksi potensi konflik di masyarakat sejak dini sehingga konflik bisa dicegah sejak awal.

Kehadiran negara diperlukan dalam proses deteksi dini terhadap kerawanan sosial yang mungkin meledak menjadi konflik. Untuk lebih menjamin efektivitas pengembangan mekanisme deteksi dini, setidaknya ada empat syarat yang harus dipenuhi: sensitivitas, koordinasi multi level, kelengkapan dan ketuntasan informasi, dan fairness. ${ }^{80}$

FKDM sebagai perangkat yang dibangun untuk mendeteksi sejak dini potensi konflik masyarakat, bertugas untuk masuk ke lapisan paling bawah untuk mendeteksi potensi konflik. ${ }^{81}$ Di setiap kecamatan, dibentuk FKDM sehingga deteksi dini berjalan cukup efektif. ${ }^{82}$ FKDM kecamatan berkoordinasi dengan Babinkamtibmas, Babinsa dan Lurah. Koordinasi lembaga-lembaga ini sampai saat ini dinilai cukup efektif untuk meredam potensi-potensi konflik berbasis agama. ${ }^{83} \mathrm{Di}$ samping itu, polisi melalui

\footnotetext{
${ }^{79}$ Wawancara dengan Amrozi, Humas Kesbangpol, 25 Mei 2016.

${ }^{80}$ Karnaji, dkk., "Social Early Warning System."

81 Wawancara dengan Amrozi, Humas Kesbangpol, 25 Mei 2016.

82 Wawancara dengan Doni Bayu Setiawan, anggota DPRD II Bojonegoro dari PDI-P, 27 Mei 2016.

83 Wawancara dengan Amrozi, Humas Kesbangpol, 25 Mei 2016.
} 
perangkat intelkam nya juga melakukan pencegahan secara aktif, sebagaimana yang terlihat dalam kasus Syiah.

Kehadiran negara juga diwujudkan melalui kehadiran aktif FKUB terhadap kelompok-kelompok minoritas rentan. Inilah yang bisa dilihat pada pengakuan dari komunitas Syiah.

"Kalau FKUB kita ada namanya Pak Sonu ya mas.... Kita sangat baik hubungannya. Beliau pernah datang kemari dan kita juga sering sowan ke sana. Beliau bilang kalau ada apa-apa malah suruh segera menghubungi beliau. Sesekali beliau bersama Bupati datang di acaraacara pengajian kami." 84

Pernyataan Rifai di atas menunjukkan bahwa sekalipun sudah ada perangkat struktural khusus yang dibentuk untuk memastikan kehadiran negara, Bupati Suyoto dalam beberapa momentum memastikan dirinya sendiri untuk hadir. Perlu juga dicatat di sini, bahwa Bupati juga mengambil peran mediator langsung dalam konflik Klenteng Hok Swie Bio.

Untuk memastikan kehadiran negara dan perlindungan negara terhadap hak-hak berkeyakinan warganya, pada tahun 2015, Bupati mengeluarkan Perbup Nomor 7 tentang Kabupaten Ramah Hak Asasi Manusia. Di dalamnya, dinyatakan bahwa pemerintah daerah wajib menciptakan lingkungan aman yang dapat mengurangi risiko kekerasan. Aparat keamanan juga diwajibkan selalu menjunjung tinggi HAM. Sementara untuk hak berkeyakinan, di sana dinyatakan bahwa pemerintah daerah wajib memenuhi hak individu dan tidak melakukan diskriminasi atas dasar agama. ${ }^{85}$

Oleh kalangan Islamis, peraturan bupati ini dianggap sebagai titipan kelompok luar yang memiliki agenda dan kepentingan yang tidak sesuai dengan keyakinan masyarakat Bojonegoro. ${ }^{86}$ Namun beberapa informan

\footnotetext{
${ }^{84}$ Wawancara dengan Irfan Rifa'i, Ketua Branis Community, organisasi sosial pengikut Syiah Bojonegoro, dan Andik, 19 Mei 2016.

${ }^{85}$ Lihat Peraturan Bupati Bojonegoro Nomor 7 Tahun 2015 tentang Kabupaten Ramah Hak Asasi Manusia, terutama pada bab 7 pasal 13 dan bab 8 pasal 14 .

${ }^{86}$ Wawancara dengan Ikhwadun, 28 Mei 2016.
} 
menyatakan bahwa proses penerbitan peraturan tersebut sudah dikonsultasikan dengan berbagai pihak yang berkepentingan di Bojonegoro. Pengurus NU Bojonegoro menyatakan bahwa "Itu memang hasil musyawarah dengan kita dan beberapa tokoh." ${ }^{17}$ Keterangan ini dibenarkan oleh Doni, anggota DPRD II Bojonegoro dari PDI-P, yang menyatakan bahwa sejak awal pihak dewan sudah diajak berbicara, "Kemudian Bupati melalui SKPD dan seterusnya, termasuk Bakesbangpol, FKUB dan tokoh-tokoh lintas agama dipanggil, kemudian merumuskan itu, baru kemudian dilaporkan kepada dewan." ${ }^{88}$

Terlihat jelas bahwa dalam menjaga harmoni sosial, terutama kehidupan keagamaan, pemerintah Kabupaten Bojonegoro melakukan berbagai kebijakan politis yang cukup efektif. Kebijakan-kebijakan politis itu setidaknya bisa dirinci ke dalam beberapa fungsi: fungsi pencegahan dini, fungsi koordinatif, fungsi regulatif, dan fungsi sebagai mediator. Keempat fungsi ini dijalankan untuk memastikan hadirnya negara dalam setiap kemungkinan lahirnya konflik, dengan tetap memosisikan dirinya sebagai wasit yang netral dan tegas.

\section{Penutup}

Sekalipun Bojonegoro secara umum diidentifikasi sebagai kabupaten yang nyaris nirkekerasan bermotif agama, namun membayangkan Bojonegoro sebagai wilayah yang sepenuhnya toleran dan memberi rasa nyaman kepada setiap pemeluk keyakinan juga bisa menyesatkan. Dari keseluruhan paparan di atas, jelas sekali bahwa Bojonegoro juga menyimpan potensi konflik yang kalau tidak dikelola secara tepat, bisa meledak menjadi konflik terbuka yang destruktif dan tidak bisa terkontrol. Potensi konflik itu setidaknya bisa dilihat pada dua hal. Pertama, bekerjanya prasangka negatif pada sebagian masyarakat terhadap kelompok lain yang berbeda keyakinan. Upaya pengusiran Syiah dan MTA serta penolakan pembangunan Gereja Bethany menandakan adanya sentimen negatif yang

\footnotetext{
${ }^{87}$ Wawancara dengan Mazroi, Sekretaris PCNU Bojonegoro, 25 Mei 2016.

88 Wawancara dengan Doni Bayu Setiawan, anggota DPRD II Bojonegoro dari PDI-P, 27 Mei 2016.
} 
mengendap pada sebagian kalangan masyarakat terhadap kelompok keyakinan lain.

Kedua, adanya kelompok-kelompok keagamaan yang bersifat eksklusif dengan ideologi keagamaan yang cenderung radikal. Kelompok ini, kalaupun hingga saat ini tidak melakukan aksi-aksi kekerasan atas nama agama, namun mereka menyetujui aksi-aksi kekerasan oleh masyarakat sipil terhadap orang atau kelompok orang yang dianggap melakukan perbuatan dosa. Persetujuan ini diambil berdasarkan pemahamannya atas konsep jihad dan amar makruf nahi munkar. Kelompok ini bahkan mengidamkan Bojonegoro sebagai kabupaten Islam seperti Aceh.

Jika hingga kini kekuatan radikal tidak bisa berkembang di Bojonegoro, penelitian ini menemukan dua faktor yang mampu menjaga kehidupan keagamaan masyarakat Bojonegoro tetap seimbang: kultural dan struktural.

Beberapa hal yang masuk dalam faktor kultural adalah: Pertama, masyarakat Bojonegoro bukanlah masyarakat agamis. Isu agama tidak cukup memiliki kekuatan untuk mengaduk sentimen negatif masyarakat. Nilai-nilai budaya yang menjadi landasan normatif masyarakat Bojonegoro adalah nilai-nilai kejawaan yang menekankan pada guyub, rukun, dan selamet. Nilai-nilai itu dalam kehidupan masyarakat Bojonegoro bukan slogan normatif kosong, namun fungsional dalam kehidupannya. "Wong hidup rukun saja susah mencari makan, apalagi kalau tidak rukun".

Kedua, bekerjanya cross-cutting affiliation. Nilai-nilai guyub, rukun, dan selamet itu dipraktikkan secara alami dalam interaksi sosial sehari-hari. Terdapat ruang-ruang sosial netral yang mempertemukan orang-orang dari latar belakang berbeda, tanpa dibebani oleh identitas-identitas primordial. Jaringan ekonomi, pertemuan-pertemuan refreshment di warung kopi, dan paguyuban-paguyuban sosial menjadi zona netral yang mampu menjaga keseimbangan warganya.

Ketiga, tokoh-tokoh agama lokal yang berpengaruh didominasi oleh kalangan yang berhaluan moderat. Tokoh-tokoh agama moderat cukup 
dominan di tubuh NU dan Muhammadiyah serta lembaga-lembaga semi negara (MUI dan FKUB) yang memiliki fungsi, langsung atau tidak langsung, dalam membangun kehidupan keagamaan yang damai. Dalam beberapa kasus yang potensial menciptakan konflik terbuka, tokoh-tokoh agama moderat ini berperan aktif dalam proses meredam dan menghentikan konflik.

Sedangkan yang masuk. Faktor Struktural adalah: Pertama, hadirnya negara (eksekutif dan aparat keamanan) sebagai pihak yang netral dan tegas. Kehadiran negara ini mampu menjaga keseimbangan sehingga tidak ada satu pun kelompok yang bisa sangat dominan. Kehadiran ini mampu menjamin setiap kelompok keyakinan mendapatkan hak-haknya secara proporsional dan terlindungi dari penyingkiran kelompok lain. Bahkan kelompok minoritas yang tidak disukai kelompok mayoritas pun mendapat jaminan perlindungan dan terbebas dari diskriminasi.

Kedua, institusionalisasi jaminan kebebasan berkeyakinan. Jaminan atas kebebasan berkeyakinan dan tidak adanya diskriminasi dilembagakan melalui regulasi formal yang memiliki kekuatan hukum mengikat.

Ketiga, negara aktif melakukan pencegahan dini dan memediasi konflik. Pemerintah daerah Bojonegoro melalui FKDM hadir sejak dini dalam mencegah konflik. Fungsi pencegahan dini ini dipadu dengan berjalannya fungsi koordinatif di berbagai level serta mediasi yang langsung diperankan oleh pemerintah daerah mampu meredam dan menghindarkan masyarakat dari konflik.

Sampai di sini, bisa dinyatakan bahwa kombinasi antara faktor kultural dan struktural cukup mampu menahan kerentanan sebagian masyarakat dari pengaruh negatif pihak luar (langsung maupun melalui media) untuk berbuat kekerasan. Beberapa peristiwa kekerasan agama yang sempat muncul tidak pernah membesar karena tidak cukup memperoleh dukungan dari masyarakat luas. Netralitas dan ketegasan negara dalam menjamin hak-hak berkeyakinan dan perlindungan warganya dari ancaman kelompok lain berfungsi seperti penyegel formal yang menggaransi kehidupan sosial yang damai. Situasi kultural dan jaminan struktural ini 
juga yang bisa menjelaskan mengapa beberapa organisasi radikal yang masuk ke Bojonegoro tidak bisa berkembang dan bahkan akhirnya mati.

\section{Daftar Pustaka}

Afdillah, Muhammad. Dari Masjid ke Panggung Politik: Studi Kasus Peran Pemuka Agama dan Politisi dalam Konflik Kekerasan Agama antara Komunitas Sunni dan Syiah di Sampang Jawa Timur. Tesis--UGM, Yogyakarta, 2013.

Agustino, Leo. "Konflik dan pembangunan politik." Analisis, CSIS, Vol. 33, No. 3 (2004).

Awwas, Irfan S. (ed.). Risalah Kongres Mujabidin dan Penegakan Syariab Islam. Yogyakarta: Wihdah Press, 2001.

Bubalo, Anthony \& Greg Fealy. Joining the Caravan? The Middle East, Islamism and Indonesia. Alexandria: Iowa Institute for International Policy, 2005.

Esposito, John L. "Muslim Moderat: Arus Utama Kelompok Modernis, Islamis, Konservatif, dan Tradisionalis." dalam Suaidi Asyari (ed.). Siapakah Muslim Moderat?. Jakarta: Kultura, 2008.

Hafi, Muhammad. Asal-usul Komunitas Pencinta Ablil Bayt Bojonegoro. Surabaya. 15 Juni 2016.

Hamdi, A.Z. "Klaim Religious Authority dalam Konflik Sunni-Syi'i Sampang Madura. Islamica. Vol. 6. No. 2 (Maret 2012).

Hefner, Robert W. "Muslim Democrats and Islamist Violence in PostSoeharto Indonesia." dalam Robert W. Hefner (ed.). Remaking Muslim Politics: Pluralism, Contestation, and Democratization. Princeton, New Jersey: Princeton University Press, 2005.

Jamhari \& Jajang Jahroni (ed.). Gerakan Salafi Radikal di Indonesia. Jakarta: Raja Grafindo Persada, 2004. 
Kaafah, Udkhulu Fissilmi. Industri dan Perubahan Sosial: Dampak Peralihan Fungsi Laban Pertanian Menjadi Industri Migas di Desa Gayam Kecamatan Gayam Kabupaten Bojonegoro. Skripsi pada Universitas Islam Negeri Sunan Ampel Surabaya. 2016.

Karnaji. dkk. "Social Early Warning System untuk Mengantisipasi Konflik Sosial di Masyarakat." http://alhada-fisip11.web.unair.ic.id.

Miller, David \& Michael Walzer (ed.). Pluralism, Justice, and Equality. New York: Oxford University Press, 1995.

Munawaroh, Siti, Chrisrtiyati Ariani, \& Suwarno. Etnografi Masyarakat Samin di Bojonegoro: Potret Masyarakat Samin dalam Memaknai Hidup. 2015.

Prasetyo, Stanley Adi, A.E. Priyono, Olle Torrnquist. (ed.). Gerakan Demokrasi di Indonesia Pasca-Soeharto. Jakarta: Demos, 2003.

Prastawa, Yopindra Ego. Implementasi Perda No. 23/2011 tentang Percepatan Pertumbuhan Ekonomi Daerah dalam Pelaksanaan Eksplorasi dan Eksploitasi serta Pengolahan Mnyak dan Gas Bumi di Kabupaten Bojonegoro. 2015.

Rahman, M. Fadjroel. "Demokrasi: Perjuangan Menegakkan Kedaulatan Rakyat, dan Masyarakat Sipil yang Toleran-kritis-Rasional." dalam Larry Diamond (ed.). Revolusi Demokrasi: Perjuangan untuk Kebebasan dan Pluralisme di negara sedang Berkembang. Ter. Matheos Nalle. Jakarta: Obor, 1994.

Rahmat, M. Imdadun. Arus Baru Islam Radikal: Transmisi Revivalisme Islam Timur Tengah ke Indonesia. Jakarta: Erlangga, 2005.

Rumadi \& Ahmad Suaedy (ed.). Politisasi Agama dan Konflik Komunal: Beberapa Isu Penting di Indonesia. Jakarta: Wahid Institute, 2007.

Saeed, Abdullah. "Trends in Contemporary Islam: A Preliminary Attempts at a Classification." The Muslim World, Vol. 97 (Juli 2007).

Sahab, Ali. Perilaku Memilih Masyarakat Bojonegoro dalam Pilkada, "Kenapa Harus 'Toto'?". 2012. 
Sukma, Rizal. "Ethnic Conflict in Indonesia: Causes and the Quest for Solution." dalam Kusuma Snitwongse \& W. Scott Thompson (ed.). Ethnic Conflict in South East Asia. Singapura: ISEAS, 2005.

Sunarti. Kerukunan Antar agama di Kampung Kristen: Studi Kasus di Dusun Kwangenrejo Desa Leran Kecamatan Kalitidu Kabupaten Bojonegoro. Skripsi pada Universitas Islam Negeri Sunan Ampel Surabaya. 2104.

Tim CMARs, Ringkasan Eksekutif Berdamai dengan Kekerasan (Fakta Tindakan Intoleransi dan Pelanggaran Hak Kebebasan Beragama/Berkeyakinan di Jawa Timur 2010).

Trigg, Roger. Religious Diversity: Philosophical and Political Dimensions. New York: Cambridge University Press, 2014. 